Article

\title{
Fundamental Active Current Adaptive Linear Neural Networks for Photovoltaic Shunt Active Power Filters
}

\author{
Muhammad Ammirrul Atiqi Mohd Zainuri 1,2,*, Mohd Amran Mohd Radzi 1,2, \\ Azura Che Soh ${ }^{1,2}$, Norman Mariun ${ }^{1,2}$, Nasrudin Abd Rahim ${ }^{3}$ and Shahrooz Hajighorbani ${ }^{1,2}$ \\ 1 Department of Electrical and Electronic Engineering, Faculty of Engineering, Universiti Putra Malaysia, \\ Serdang 43400, Selangor, Malaysia; amranmr@upm.edu.my (M.A.M.R.); azuracs@upm.edu.my (A.C.S.); \\ norman@upm.edu.my (N.M.); shahrooz.kntu@yahoo.com (S.H.) \\ 2 Centre for Advanced Power and Energy Research, Faculty of Engineering, Universiti Putra Malaysia, \\ Serdang 43400, Selangor, Malaysia \\ 3 University of Malaya Power Energy Dedicated Advanced Centre (UMPEDAC), University of Malaya, \\ Kuala Lumpur 59990, Malaysia; nasrudin@um.edu.my \\ * Correspondence: ammirrulatiqi@gmail.com; Tel.: +60-13-215-7229
}

Academic Editor: Tapas Mallick

Received: 30 March 2016; Accepted: 20 May 2016; Published: 27 May 2016

\begin{abstract}
This paper presents improvement of a harmonics extraction algorithm, known as the fundamental active current (FAC) adaptive linear element (ADALINE) neural network with the integration of photovoltaic (PV) to shunt active power filters (SAPFs) as active current source. Active PV injection in SAPFs should reduce dependency on grid supply current to supply the system. In addition, with a better and faster harmonics extraction algorithm, the SAPF should perform well, especially under dynamic PV and load conditions. The role of the actual injection current from SAPF after connecting PVs will be evaluated, and the better effect of using FAC ADALINE will be confirmed. The proposed SAPF was simulated and evaluated in MATLAB/Simulink first. Then, an experimental laboratory prototype was also developed to be tested with a PV simulator (CHROMA 62100H-600S), and the algorithm was implemented using a TMS320F28335 Digital Signal Processor (DSP). From simulation and experimental results, significant improvements in terms of total harmonic distortion (THD), time response and reduction of source power from grid have successfully been verified and achieved.
\end{abstract}

Keywords: shunt active power filter (SAPF); photovoltaic (PV); current harmonic; artificial neural network (ANN); total harmonic distortion (THD); digital signal processor (DSP); Simulink/MATLAB

\section{Introduction}

Harmonics are sinusoidal voltages or currents of frequencies that are integer multiples of the frequency at which the supply system is designed to operate. Current harmonics are more crucial than voltage harmonics because in most situations, the voltage harmonics only occur when there are current harmonics inside the power system. Current harmonics may result from nonlinear load operations produced by power electronic devices and applications which are injected into the supply network through a point of common coupling (PCC). Specifically, in smart grid systems, these problems may arise with involvement of multiple energy sources and systems which include photovoltaic (PV) grid connected systems [1-6]. Among the effects of current harmonics are capacitor blowing, equipment overheating, motor vibration and excessive neutral currents $[7,8]$. To compensate current harmonics, a powerful tool is the active power filter (APF), which is better as compared to a passive filter, since it can mitigate multiple harmonics instantaneously. Furthermore, for current harmonics mitigation or compensation, shunt active power filters (SAPF) or transformer-less APF topology is widely used [9-11]. However, besides SAPF, there are other topologies to compensate current harmonics, and 
among them are the third harmonics injection and the loss-free complex impedance (LFCI) [12,13]. The third harmonic injection uses almost same topology (full bridge inverter) as SAPF to generate injection current for current harmonics mitigation. As this approach only focuses compensation of the third harmonic order only, SAPF is definitely preferable to compensate all order of harmonics order up to the 25th. In addition, the third harmonics injection also does not cover power factor correction which causes the source current to not be in phase with the source voltage [12]. For the LFCI, its function is almost same as SAPF, where it can mitigate current harmonics and correct power factorss. It mitigates current harmonics directly at the load side by controlling the switching signal of the rectifier, and also by emulating a certain degree of input capacitance without any physical capacitance [13]. Differently, SAPF mitigates current harmonics by indirectly extracting harmonics and injecting back the current to the grid for mitigation purpose. As a result, LFCI is more complicated as compared to SAPF as it has to emulate the capacitance in order to mitigate current harmonics [13].

Integrating PV with SAPF is among the best options as this type of energy is among the most popular renewable energy sources since it is clean, inexhaustible, and free to harvest [14]. In future perspective, the prices of PV panels are getting lower by about $4 \%-12 \%$ each year [15]. In addition, the PV panels mostly have quite long lifetimes of about 25 years $[16,17]$. Even though the existing PV modules in the market have low efficiency (15\%), with the huge development of the latest PV cell technology and in addition to the use of nanotechnology, their efficiencies can be improved by up to $40 \%[18,19]$. Meanwhile, normal SAPF extracts source current from the grid to charge the dc link capacitor. Considering the high electricity tariffs now and in the future [20], the charging process of the dc link capacitor will lead to incremental cost and strong dependency on the grid power. By having additional PV sources integrated with SAPF, this will reduce the usage of electricity from the source grid. Subsequently, integration of PV to SAPF is worthwhile due to the reduction of PV prices, long lifetime, improved efficiency and lowered usage of electricity. For functionality of PV with SAPF, the injection current consists of not just reactive current but also active current. Normal SAPF mitigates current harmonics by injecting the reactive current, but when it is operated with PV, it does not just mitigate current harmonics but also reduces source current simultaneously. With active and reactive injections to the source grid, the power quality of the grid can be improved with low total harmonic distortion (THD) values [21]. Besides reducing the source current, by integrating PVs with SAPF, the active current is also supplied to the load sides which simultaneously reduces the burden of the source current to satisfy the load demand [22]. The normal SAPF based on voltage source inverter needs to absorb active power to charge the dc link capacitor, but with integration of PV to SAPF, the PV source does not just producing active current to the grid but also helping to maintain the dc link capacitor by giving additional charging current [23].

In addition, the wide and easy installation of PV modules on the roof tops of building and also at minimal space locations provide flexibility and opportunity to connect them with any type of power electronic converter [24]. Installation of SAPF to be close to the PV source seems to be possible too, which provides strong motivation for integrating both of them. Basically, the higher the irradiance, the higher the power of the PV, which leads to lower power consumption from the grid to supply the load, or specifically can be in related to the reduction of source current. However, change of irradiance and subsequently inappropriate injection of current from SAPF may degrade the performance of the overall system.

The role of the harmonics extraction algorithm is important in order to ensure an appropriate injection current from SAPF. Through better injection, the SAPF should be able to compensate harmonics optimally $[25,26]$. Numerous methods have been used to extract harmonics in past research works, which include d-q axis with Fourier (DQF) [27-29], instantaneous reactive power theory ( $p-q)$ theory [30], adaptive filters [31], wavelet [32], synchronous reference frame (SRF) [33], synchronous detection [34], artificial neural network (ANN) [35], and many more. ANN is the latest trend because of its capability to perform fast, accurately and stably. Specifically, for SAPF, ANN will accurately 
estimate or extract time-varying fundamental components, both the magnitude and the phase angle, to mitigate harmonic components [36,37].

There are numerous ANN architectures for harmonics extraction such as adaptive linear neuron (ADALINE), Perceptron, Back propagation (BP), radial basis function (RBF), Hopfield, Hebbian, Competitive, and Grossberg [38,39]. Among them, ADALINE is preferable because of it only consists of one linear system and its simplicity to perform a good harmonics extraction. A number of works have been carried out using ADALINE for current harmonics extraction. One of them is a single linear neuron model method, which is called as Widrow-Hoff (W-H) ADALINE Neural Network. However, the disadvantage of W-H ADALINE is it must learn multiple harmonic components which had an effect on the learning time of the algorithm itself $[39,40]$. Improvements have been carried out to improve the algorithm by focusing directly on extraction of the fundamental component with a suitable learning rate in updating the algorithm, which is called modified Widrow-Hoff $(\mathrm{W}-\mathrm{H})$ ADALINE $[35,39,41]$.

Further improvements have to be made because the existing improvemente are still considered as having needless features which do not represent the basic requirements for extracting current harmonics in power systems. With these needless features, some drawbacks affect performance of the Modified W-H ADALINE such as the large size average error and slow learning rate due to the cosine component and weight factor that may affect its time response, and as a result, delay in compensation [42]. As PV is known to be dynamically affected by changes of irradiance, the harmonics extraction algorithm plays crucial function to maintain proper and fast response injection current with additional PV current to mitigate the current harmonics existing in the power system.

This paper first presents integration of PV to SAPF with significant investigation on generation of active PV currents. Second, a new simplified and improved ADALINE neural network for harmonics extraction is proposed, which is later called the fundamental active current (FAC) ADALINE algorithm. In the proposed algorithm, three major improvements have been made to the learning updating technique, sine and cosine vector, and sum of elements. Evaluation of the proposed algorithm under significant effect of PV sources will be carried out to confirm its effective operation in SAPF. Reduction of THD, response time, and source power from grid should be verified. Further explanation on the proposed SAPF with active PV current, new proposed current harmonics extraction algorithm, simulation and experimental results, and conclusions are presented Sections 2-6 respectively.

\section{Integration of Photovoltaic with Shunt Active Power Filter}

Figure 1 shows a block diagram of a SAPF connected with a PV array and the control strategies inside it. Without $P V$, nonlinear-load operation contains load current $I_{\mathrm{L}}$, which comprises fundamental component $I_{\mathrm{f}}$ and harmonic component $I_{\mathrm{H}}$, both present within the grid source current $I_{\mathrm{S}}$, polluting the power system. After the SAPF is connected, it generates an injection current $I_{\text {inj }}$ which then compensates the harmonic current produced by the load, as shown below:

$$
I_{\mathrm{S}}=I_{\mathrm{L}}-I_{\mathrm{inj}}=I_{\mathrm{f}}+I_{\mathrm{H}}-I_{\text {inj }}
$$

The injection current $I_{\text {inj }}$ is generated from the inverter-based configuration of SAPF, or can be defined as $I_{\text {inv }}$. If the inverter current $I_{\text {inv }}$ is equal to harmonic current $I_{\mathrm{H}}$, then source current $I_{\mathrm{S}}$ will only comprise the fundamental component $I_{\mathrm{f}}$. Meanwhile, by arranging Equation (1) and using inverter current $I_{\text {inv }}$, the load operates based on combination of source current $I_{S}$ and inverter current $I_{\text {inv }}$, as shown below:

$$
I_{\mathrm{L}}=I_{\mathrm{S}}+I_{\mathrm{inv}}
$$

However, by connecting PV, as shown in Figure 1a, the PV current $I_{P V}$ is injected together with inverter current $I_{\text {inv }}$, or:

$$
I_{\mathrm{L}}=I_{\mathrm{S}}+I_{\mathrm{inv}}+I_{\mathrm{PV}}
$$



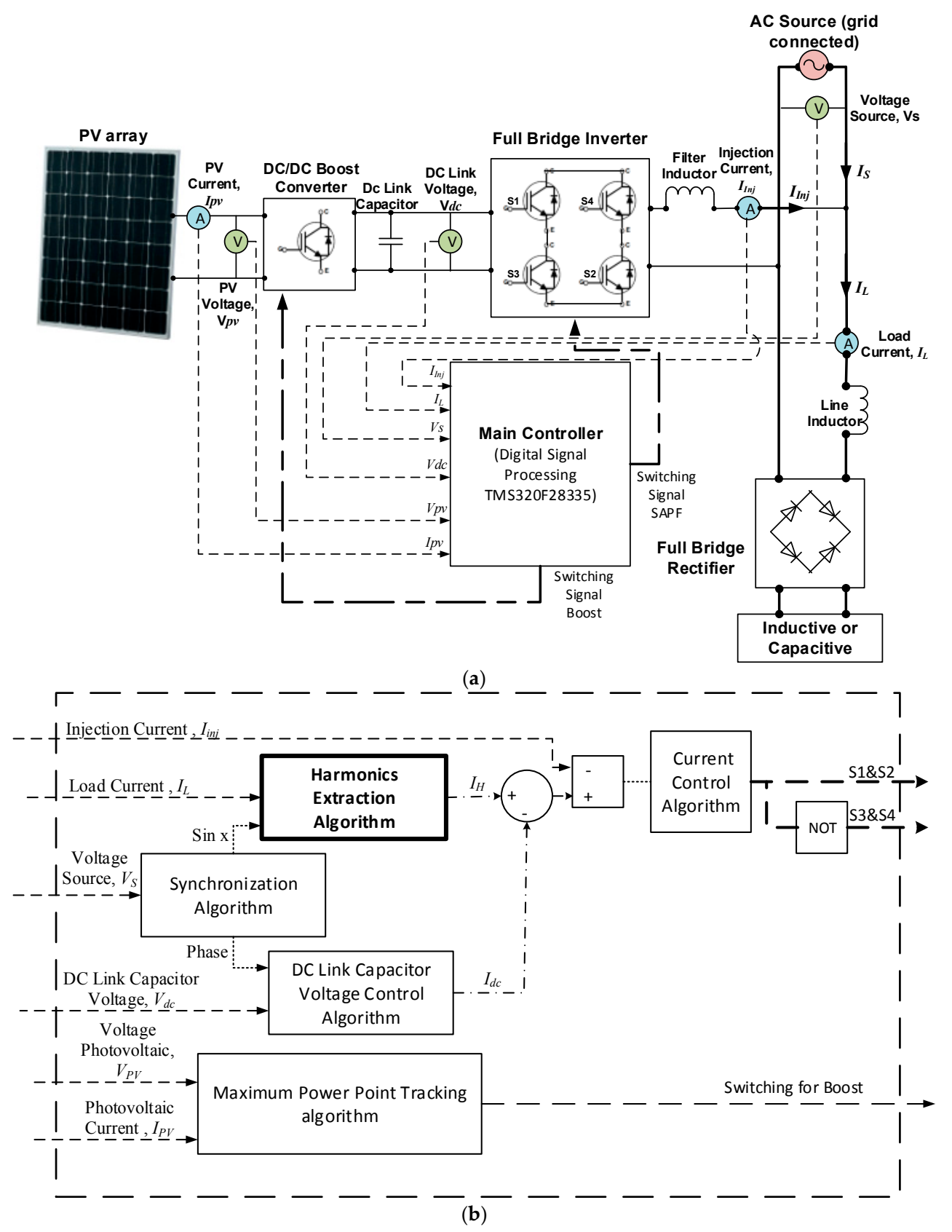

Figure 1. Diagram of (a) shunt active power filter (SAPF) integrated with PV and (b) control strategies inside it.

Considering with the same amount of current needed by the load before and after connecting the $\mathrm{PV}$, the source current $I_{\mathrm{S}}$ should be reduced with significant effect from the PV current $I_{\mathrm{PV}}$. Therefore, the injection current $I_{\mathrm{inv}}$ at PCC now is combination of inverter current $I_{\mathrm{inv}}$ and PV current $I_{\mathrm{PV}}$, or:

$$
I_{\text {inj }}=I_{\text {inv }}+I_{\mathrm{PV}}
$$

The role of the injection current is crucial as it will determine performance of the SAPF with the combination of PV sources. Fast and accurate injection current will lead to better operation of the SAPF. The PV current to be added to the system is totally dependent on the irradiance of the Sun. High irradiance will give a high PV current which leads to low current usage taken from the grid system. According to Equation (4), the inverter current $I_{\text {inv }}$ is controlled by the combination of the 
harmonics extraction algorithm and dc link capacitor voltage control, and meanwhile, the PV current is controlled by the maximum power point tracking (MPPT) algorithm.

The size of the PV array is fully dependent on the configuration of the SAPF and power rating of the source grid. By connecting PV, the SAPF may operate with a full bridge inverter to be directly connected to PVs, which is called as single-stage configuration, or with addition of a dc/dc converter, which is called two-stage configuration [21-23]. The advantage of the single-stage configuration is lower power losses; however, it needs a higher number of PV modules in order to supply enough voltage to the dc link capacitor, which may make the overall system become bigger. Meanwhile, by having a two-stage configuration, although it may have losses, a lesser number of PV modules is required, which directly reduces the cost. In addition, there is the flexibility of controlling the PV voltage for a dc link capacitor. Thus, this work uses a two-stage configuration, as shown in Figure 1. In terms of power rating, the SAPF with PV works well as long as the maximum power of the PV array is not above the rating of the source power. Higher maximum power of the PV array over the source power will result in inaccurate current injection for the purpose of harmonics mitigation. The proposed PV module used is a monocrystalline silicon type with the characteristics listed in Table 1.

Table 1. Characteristics of the PV module (Model: SHARP NT-180U1) at $1000 \mathrm{~W} / \mathrm{m}^{2}$ irradiance.

\begin{tabular}{ccc}
\hline Parameter & Value & Unit \\
\hline Open circuit voltage, $V_{\mathrm{oc}}$ & 44.8 & $\mathrm{~V}$ \\
Voltage at maximum power, $V_{\mathrm{mp}}$ & 35.86 & $\mathrm{~V}$ \\
Short circuit current, $I_{\mathrm{sc}}$ & 5.60 & $\mathrm{~A}$ \\
Current at maximum power, $I_{\mathrm{mp}}$ & 5.02 & $\mathrm{~A}$ \\
Maximum power, $P_{\max }$ & 180 & $\mathrm{~W}$ \\
\hline
\end{tabular}

The PV modules connected in an array are connected to boost the dc/dc converter used to step up the PV voltage and is the medium where the maximum power point tracking (MPPT) algorithm works. The main function of the MPPT algorithm is to track and maintain the maximum power point of the PV array according to the irradiance. The boost dc/dc converter is connected to a full bridge inverter through a dc link capacitor. In the integration of PV and SAPF, the main part is the controller which covers all the control strategies, including MPPT algorithm, harmonics extraction algorithm, dc link capacitor voltage control algorithm, synchronization algorithm, and current control algorithm. As shown in Figure 1b, the highlighted algorithm is the harmonics extraction algorithm. For the MPPT algorithm, a so-called adaptive perturb and observe ( $\mathrm{P} \& \mathrm{O})$-fuzzy algorithm is used due to its better performance of tracking the maximum power point under dynamic operations [43]. To control the dc link capacitor voltage, self-charging with step size error cancellation is used [44]. As current control algorithm, a linear current control algorithm which consists of a proportional-integral (PI) technique for steady state error control, with pulse width modulation (PWM) for producing switching signals for power switching devices, is chosen because its simplicity and easy implementation $[36,41,45]$. The value for proportional gain $\left(k_{\mathrm{p}}\right)$ is 200 and the integral gain $\left(k_{\mathrm{i}}\right)$ is 37 . A synchronizer based on the ANN method, or called as unified ADALINEs-based fundamental voltage extraction algorithm, is used to produce a reference sinusoidal signal [46]. The source of harmonics is from a rectifier-based circuit with nonlinear loads, connected to the grid, which produces current harmonics in electrical power systems [47-52].

\section{Fundamental Active Current ADALINE Algorithm}

As explained earlier, the proposed harmonics algorithm is based on significant improvements to the Modified Widrow-Hoff (W-H) ADALINE, as successfully implemented in [35,36,41]. As to ensure clear understanding, some significant parts of the Modified W-H ADALINE are explained first. The Modified W-H ADALINE uses the first order of harmonic component as shown in Figure 2a. It needs only to update the two weights of the fundamental component, making it independent of the number of harmonic orders. This improvement is based on the mathematical relationship of the 
elements being orthogonal to each other. This modification leads to enhanced iteration speed which resulting in faster estimation. However, updating only the two weights results in a large average square error e, and thus learning rate $\alpha$ must be added as in Equation (5) [35]. Average square error $e(k)$ is the difference between the actual measured signal $I_{\mathrm{L}}(k)$ and the estimated signal $I_{\mathrm{est}}(k)$ :

$$
\bar{W}(k+1)=\bar{W}(k)+\frac{\alpha e(k) \bar{Y}(k)}{\bar{Y}^{T}(k) \bar{Y}(k)}
$$

where:

$$
\begin{aligned}
& \bar{W}=\left[\begin{array}{l}
w_{11} \\
w_{21}
\end{array}\right] \text { is the weight factor; } \\
& \bar{Y}=\left[\begin{array}{l}
\sin \left(k \omega t_{\mathrm{S}}\right) \\
\cos \left(k \omega t_{\mathrm{S}}\right)
\end{array}\right] \text { is the fundamental sin and cosine; } \\
& e(k)=I_{\mathrm{L}}(k)-I_{\text {est }}(k) \text { is the average square error; } \\
& \alpha \text { is the learning rate. }
\end{aligned}
$$

A suitable learning rate is important as it will help the algorithm optimally produce an accurate distorted current fundamental [35]. Good compromise between accuracy and speed should be considered in order to have the optimum value, as too low a value may result in slow performance, but too high a value may result in the algorithm failing to achieve high accuracy. Meanwhile, in practical approach, the fundamental sin and cosine can be formed based on the referenced sinusoidal signal produced by the synchronizer, as introduced earlier. The harmonic current $I_{\mathrm{H}}(k)$ can be produced from load current deduction (from load current's fundamental sine part) as in Equation (6) [35]:

$$
I_{\mathrm{H}}(k)=I_{\mathrm{L}}(k)-W \sin \left(k \omega t_{\mathrm{S}}\right)
$$

As mentioned, although the Modified W-H ADALINE algorithm is capable of mitigating harmonics with THD to be below than 5\%, but it still has some drawbacks that may affect the performance of the harmonics extraction, especially the time response to extract all the harmonics. Inside its algorithm, there are still needless features which do not represent the basic requirement of extracting current harmonics. Thus, the proposed algorithm simplifies and improves it. The three improvements are the cosine component is removed and only the sine component exists in periodic signal, the sum of elements is removed to minimize and control the large average square error $e$, and proper representation of the learning updating technique from weight updating technique to FAC updating technique. All the improvements are shown in Figure $2 \mathrm{~b}$. The first feature is removal of the cosine component in the periodic signal. In symmetrical theory, an odd function is inversely symmetrical about the $y$-axis, which means only the sine component exists in the odd function of periodic signals. Since the cosine component is removed, automatically the second improvement can be made where the sum of elements is removed which reduces the large average square error $e$. The last improvement is by representing the learning factor in the learning updating technique as in Equation (7):

$$
I_{\mathrm{f}}(k+1)=I_{\mathrm{f}}+\frac{\alpha e(k)}{\sin \left(k \omega t_{\mathrm{s}}\right)}
$$

The learning factor by using weight $W$ in Equation (6) does not give a clear representation for functionality of SAPF. The weight learning factor can be represented as the peak value of active fundamental current before it is multiplied by the sine component. To make it simpler and understandable, the real learning factor is directly renamed as FAC $I_{\mathrm{f}}$. This new renamed parameter will provide a better idea by directly giving information of required value for generating injection current. The FAC updating technique is shown in Figure 2. The new equation of harmonic current is:

$$
I_{\mathrm{H}}(k)=I_{\mathrm{L}}(k)-I_{\mathrm{f}} \sin \left(k \omega t_{\mathrm{s}}\right)
$$




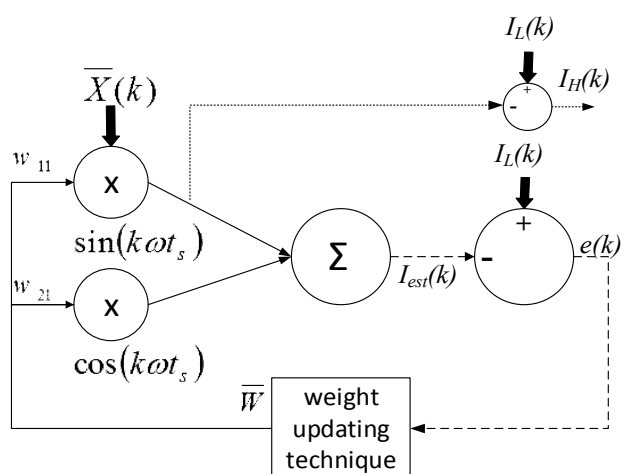

(a)

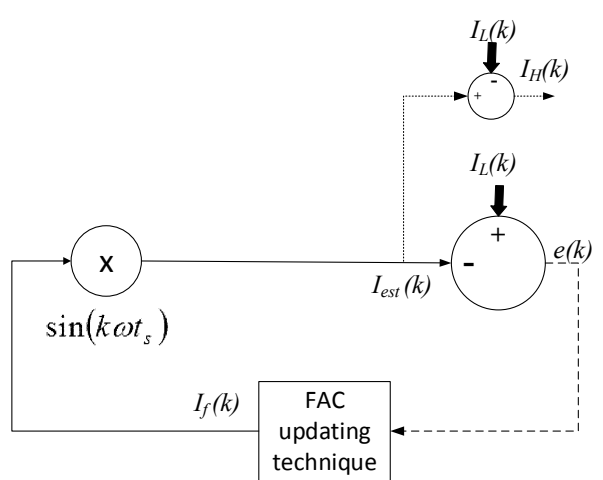

(b)

Figure 2. The harmonics extraction algorithms of (a) modified Widrow-Hoff (W-H) ADALINE algorithm and (b) fundamental active current (FAC) ADALINE algorithm.

\section{Simulation Results}

A SAPF with PV array was developed and simulated using the MATLAB/Simulink simulation software. Table 2 lists each component used for the proposed SAPF. The detailed calculations for determining the values of the $\mathrm{dc}$ link capacitor, $\mathrm{dc} / \mathrm{dc}$ boost inductor and filtering inductor was based on $[53,54]$. Specifically, for the dc link capacitor, a bigger value is needed for minimizing the ripple voltage [52,55]. Two types of nonlinear loads were developed by using a diode $\mathrm{H}$-bridge rectifier with $470 \mu \mathrm{F}$ capacitor and $50 \Omega$ resistor (capacitive load) connected in parallel as the first one, and meanwhile a $160 \mathrm{mH}$ inductor and $15 \Omega$ resistor (inductive load) connected in series for the second one. Duty cycle for dc/dc boost converter was set to 0.28 . A dynamic operation test was done to evaluate the performance of both harmonics extraction algorithms. Dynamic operations are referred to the off-on operation between PV and SAPF, and change of irradiances for the PV source. For the first dynamic operation, the irradiance during off state was set to $0 \mathrm{~W} / \mathrm{m}^{2}$, and during on state was set to $600 \mathrm{~W} / \mathrm{m}^{2}$. Meanwhile, for the second dynamic operation, the change of irradiances is between low $\left(200 \mathrm{~W} / \mathrm{m}^{2}\right)$ to high $\left(1000 \mathrm{~W} / \mathrm{m}^{2}\right)$ irradiance. The sampling time for this simulation was set to $6.67 \mu$ s with sampling frequency of $150 \mathrm{kHz}$. The switching frequency for the switching signal of the power switching devices was set to $25 \mathrm{kHz}$. Meanwhile, the learning rate for both harmonics extraction algorithms was set to 0.001 , as the setting approach has clearly been discussed in $[32,50]$.

Table 2. Components used for the proposed SAPF.

\begin{tabular}{ccc}
\hline Component & Value & Unit \\
\hline Direct current link capacitor & 2200 & $\mu \mathrm{F}$ \\
Direct current boost inductor & 400 & $\mu \mathrm{H}$ \\
Filtering inductor & 5 & $\mathrm{mH}$ \\
Direct current link capacitor voltage & 400 & $\mathrm{~V}_{\mathrm{dc}}$ \\
Source grid voltage & 230 & $\mathrm{~V}_{\mathrm{rms}}$ \\
\hline
\end{tabular}

The FAC ADALINE algorithm was evaluated and compared with the Modified W-H ADALINE, as the existing algorithm [35]. Figure 3 shows the results obtained for off-on operation and change of irradiances using capacitive and inductive loads. Meanwhile, Figure 4 shows the results obtained for change between nonlinear loads. Figure 5 shows harmonics spectrum of the nonlinear loads' currents and the source currents for operation of SAPF without PV. The nonlinear loads' currents were recorded with THD in about $40.28 \%$ for inductive load, and meanwhile, for capacitive load, the THD is about $106.31 \%$. Another additional analysis is power consumption required from the grid by considering integration of PV and SAPF. THD is also measured to evaluate significant effect due to injection of active PV current. By referring again to Figure $3 a, b$, and Figure 5 when the PV is in off condition 
(irradiance at $0 \mathrm{~W} / \mathrm{m}^{2}$ ), both algorithms show good source current waveforms with low THDs and very good elimination for all harmonic orders; yet, the proposed algorithm still gives the best results with better THD values, which are about $1.5 \%$ (inductive) and $2.29 \%$ (capacitive). Meanwhile, the existing algorithm gives about $2 \%$ (inductive) and $3.13 \%$ (capacitive). In addition, the source current is in phase with the source voltage.

When PV is connected to the SAPF, active current injection from the PV source will reduce the source current from the grid to supply and maintain the load current demand. This reduction will result in a small increase of the value of THD. With this condition, the harmonics extraction algorithms play a crucial role to maintain the THD value $5 \%$. As shown in Figure $3 a, b$ too, when PV is in on condition (irradiance at $600 \mathrm{~W} / \mathrm{m}^{2}$ ), both algorithms have maintained the THD values within $5 \%$, but the proposed algorithm gives the lower values for both nonlinear loads. The values are $1.8 \%$ (inductive) and 2.93\% (capacitive), and meanwhile the existing algorithm gives about 2.3\% (inductive) and $3.6 \%$ (capacitive). The same goes to the other two irradiances as shown in Figure $3 c, d$, where at $200 \mathrm{~W} / \mathrm{m}^{2}$, the proposed algorithm produces better THD values, which are $1.57 \%$ (inductive) and $2.82 \%$ (capacitive), and meanwhile the existing algorithm gives about $2.14 \%$ (inductive) and $3.24 \%$ (capacitive).
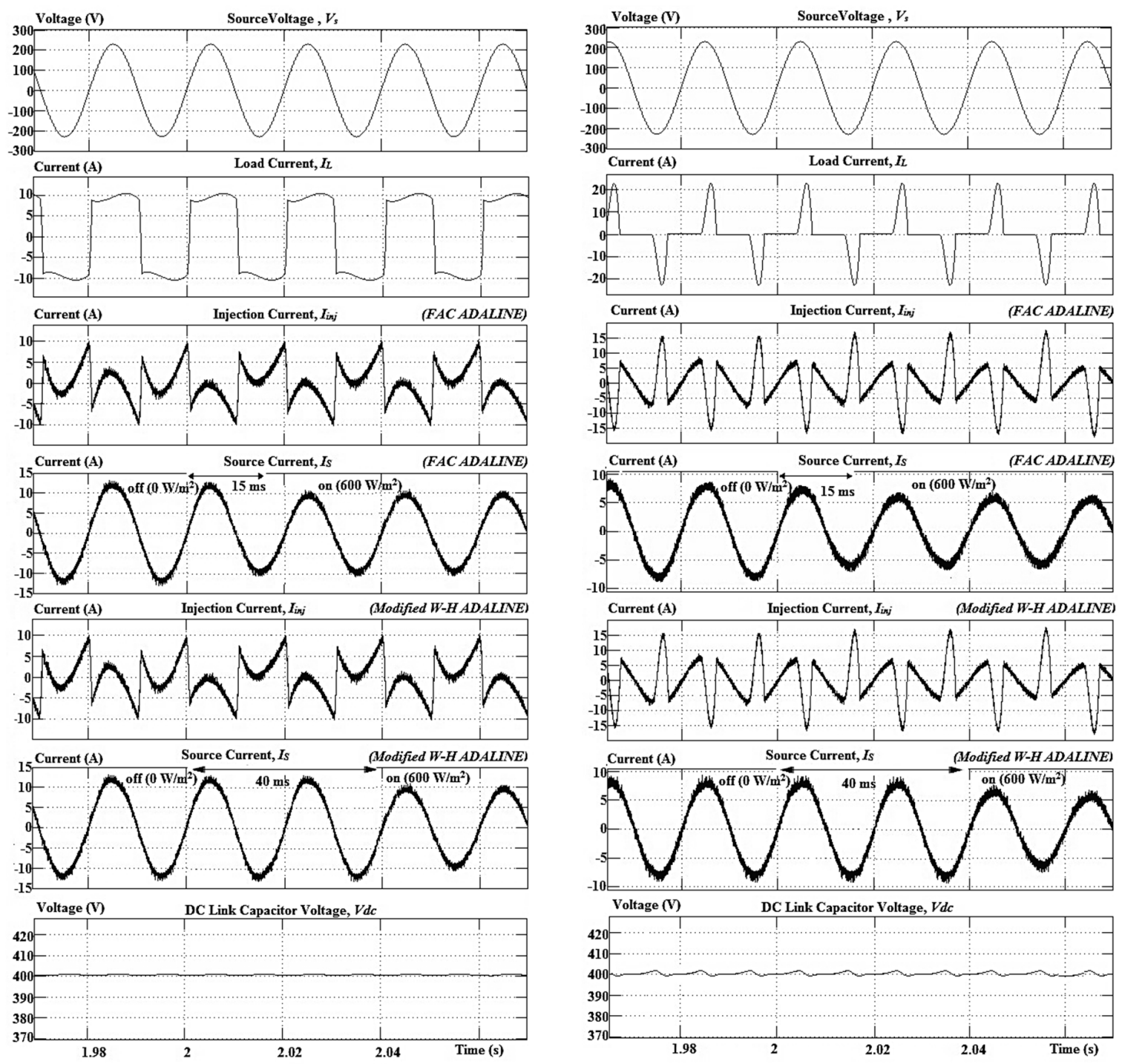

(a)

(b)

Figure 3. Cont. 


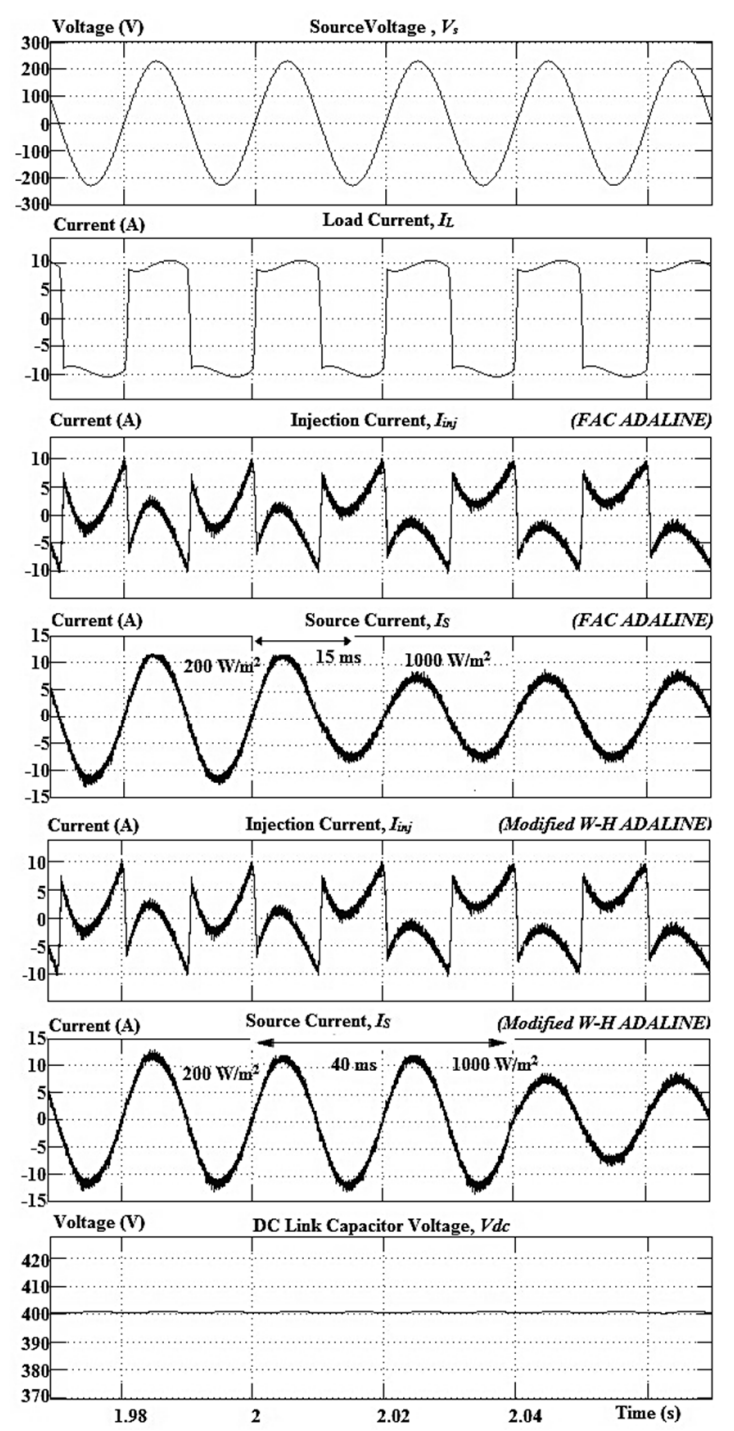

(c)
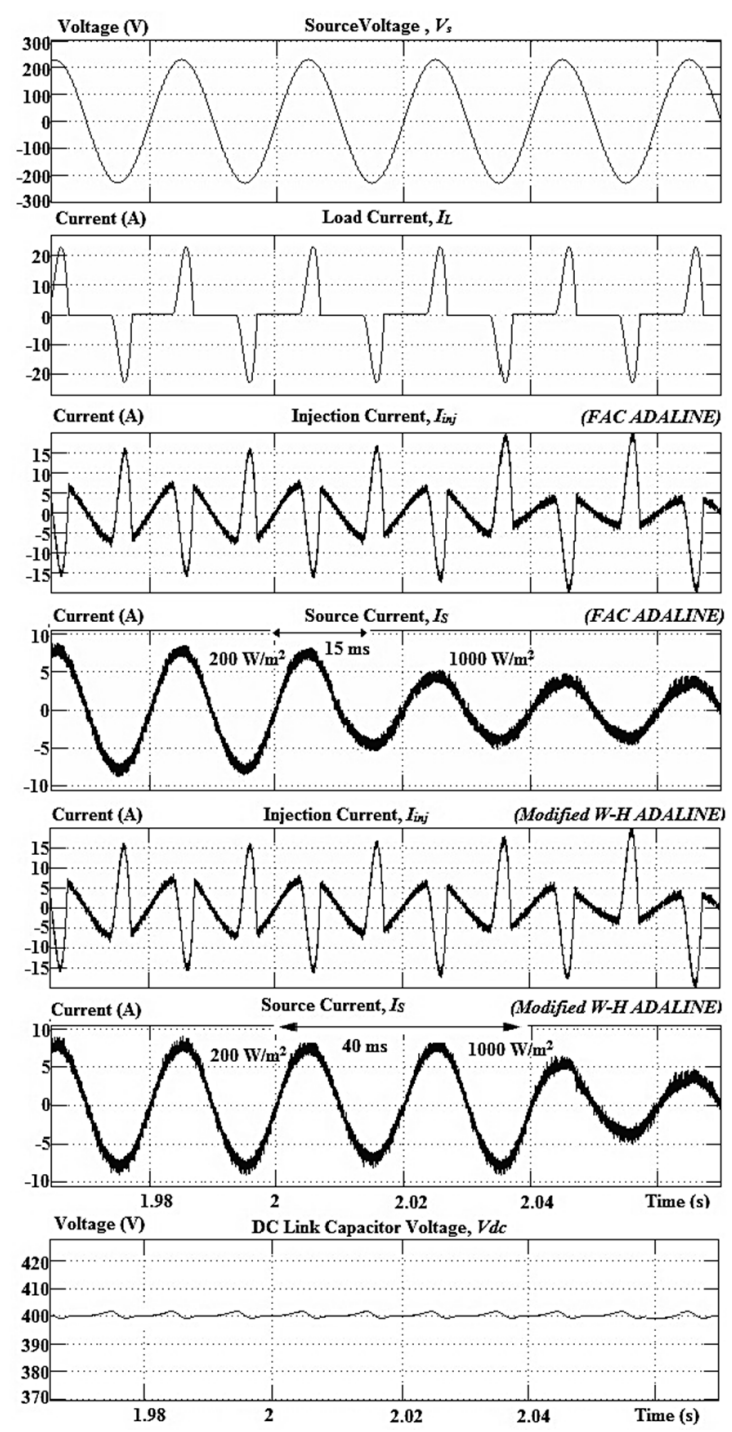

(d)

Figure 3. The waveforms of the voltage source $V_{\mathrm{S}}$, load current $I_{\mathrm{L}}$, injection current $I_{\text {inj, }}$, source current $I_{\mathrm{S}}$ and dc link capacitor voltage $V_{\mathrm{dc}}$ for dynamic operations using both harmonics extraction algorithms for (a) off-on between PV and SAPF using inductive load; (b) off-on between PV and SAPF using capacitive load; (c) change of irradiances using inductive load; and (d) change of irradiances using capacitive load.

At $1000 \mathrm{~W} / \mathrm{m}^{2}$, again, better THD values are obtained by the FAC ADALINE algorithm with $2.43 \%$ (inductive) and 3.24\% (capacitive), and meanwhile the existing algorithm gives about $2.72 \%$ (inductive) and 3.86\% (capacitive). Table 3 provides detailed comparison of THD values between both algorithms with capacitive and inductive loads.

Table 3. Simulation results of total harmonic distortion (THD) for each harmonics extraction algorithm.

\begin{tabular}{|c|c|c|c|c|c|c|c|c|}
\hline \multirow{3}{*}{$\begin{array}{l}\text { Harmonics Extraction } \\
\text { Algorithm }\end{array}$} & \multicolumn{8}{|c|}{ THD (\%) } \\
\hline & \multicolumn{4}{|c|}{ Inductive } & \multicolumn{4}{|c|}{ Capacitive } \\
\hline & $0 \mathrm{~W} / \mathrm{m}^{2}$ & $200 \mathrm{~W} / \mathrm{m}^{2}$ & $600 \mathrm{~W} / \mathrm{m}^{2}$ & $1000 \mathrm{~W} / \mathrm{m}^{2}$ & $0 \mathrm{~W} / \mathrm{m}^{2}$ & $200 \mathrm{~W} / \mathrm{m}^{2}$ & $600 \mathrm{~W} / \mathrm{m}^{2}$ & $1000 \mathrm{~W} / \mathrm{m}^{2}$ \\
\hline FAC ADALINE & 1.5 & 1.57 & 1.8 & 2.43 & 2.29 & 2.82 & 2.93 & 3.24 \\
\hline Modified W-H ADALINE & 2.0 & 2.14 & 2.3 & 2.72 & 3.13 & 3.24 & 3.6 & 3.86 \\
\hline
\end{tabular}




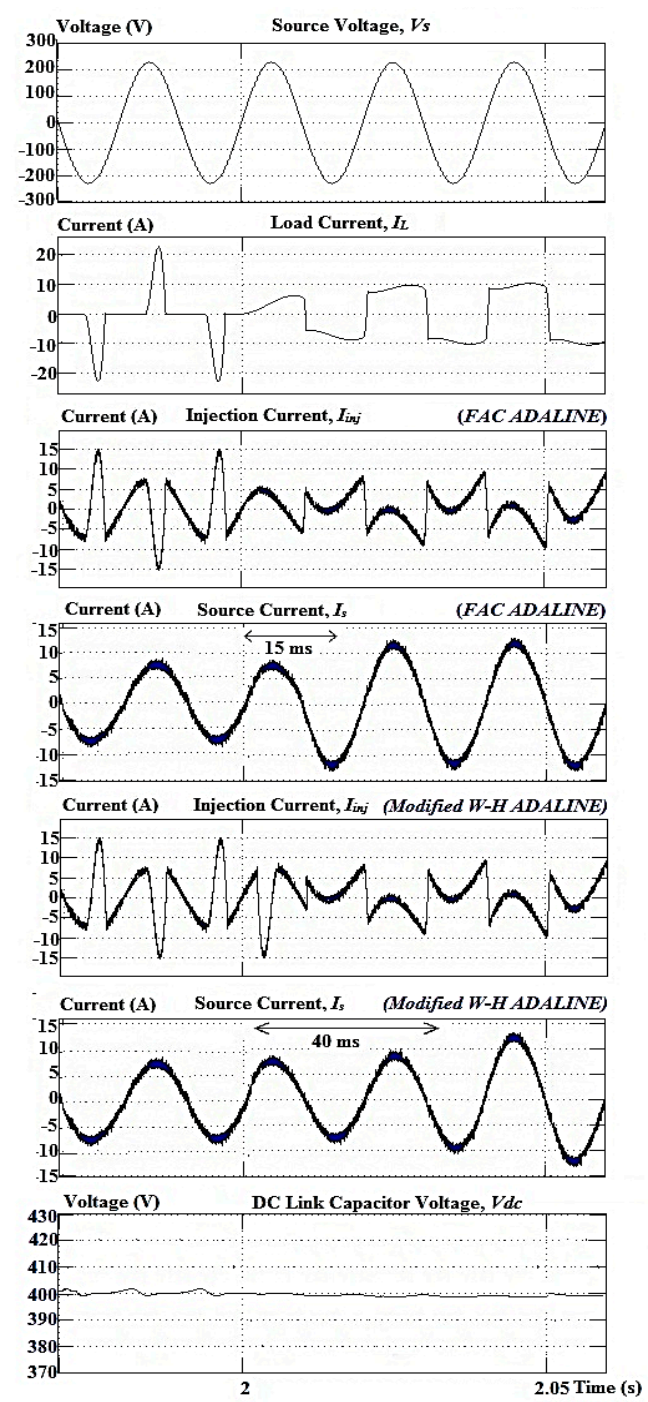

Figure 4. The waveforms of the voltage source $V_{\mathrm{S}}$, load current $I_{\mathrm{L}}$, injection current $I_{\text {inj, }}$, source current $I_{\mathrm{S}}$ and dc link capacitor voltage $V_{\mathrm{dc}}$ for change of nonlinear loads using both harmonics extraction algorithms.

Besides supplying load, the power from grid used to supply and maintain the dc link capacitor voltage of SAPF is reduced and possibly eliminated, as already covered by the PV source. The additional PV source in the SAPF also provides an alternative energy source that reduces the burden of the source grid to provide power to the load. Operation of SAPF without PV normally absorbs active power (also known real power) from the source grid for maintaining the dc link capacitor voltage and at the same time produces reactive power as to be used for compensation. Interestingly a PV source, when integrated with SAPF, will only have an effect to reduce the absorbed active power, and the SAPF now can produce both active and reactive powers. To determine how much active power supplied from the grid is reduced due to function of $\mathrm{PV}$, percentage of source power reduction $P_{\%}$ is proposed to be calculated as below:

$$
P_{\%}=\frac{P_{\mathrm{T}}-P_{\mathrm{S}}}{P_{\mathrm{T}}} \times 100
$$

where $P_{\mathrm{T}}$ is active power from the source grid when PV is in off condition (irradiance at $0 \mathrm{~W} / \mathrm{m}^{2}$ ) and $P_{\mathrm{S}}$ is active power from the source grid at certain irradiance. The $P_{\%}$ is also known as percentage of active power produced by SAPF. By referring again to Figure 3, the actual active powers from the source grid when the PV is in off condition (irradiance at $0 \mathrm{~W} / \mathrm{m}^{2}$ ) are $2714 \mathrm{~W}$ by using inductive 
load and $1794 \mathrm{~W}$ by using capacitive load. The active powers absorbed by inductive and capacitive loads are $2300 \mathrm{~W}$ and $1520 \mathrm{~W}$. Balanced active powers from the source grid are absorbed by SAPF. Meanwhile, reactive powers produced by the SAPF used for compensation are based on performances of the harmonics extraction algorithms.
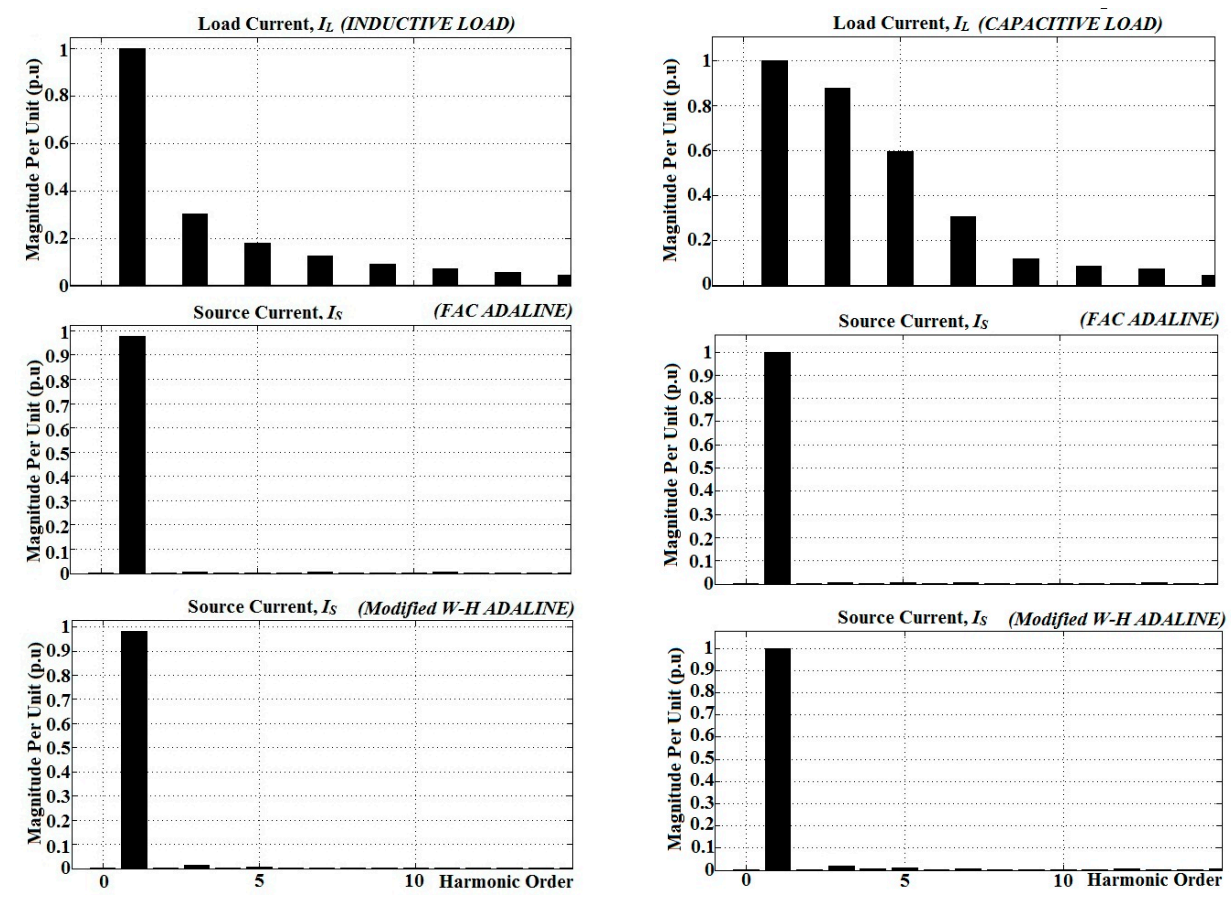

(a)

(b)

Figure 5. Harmonics spectrum of simulation work for SAPF without PV, by using both harmonics extraction algorithms, for (a) inductive and (b) capacitive loads.

By using the FAC ADALINE algorithm, the reactive powers produced for inductive and capacitive loads are 410 VAR and 270 VAR, respectively. Meanwhile, by using the Modified W-H ADALINE algorithm, the reactive powers produced are 403 VAR for inductive load and 264 VAR for capacitive load. The higher reactive powers produced by the proposed algorithm also show its better compensation performance. Furthermore, high performance of the harmonics extraction algorithm is needed in a SAPF with PV source, to have high reduction of the active power from the source grid. When the PV is in on condition at $600 \mathrm{~W} / \mathrm{m}^{2}$, the source powers greatly reduce by using the proposed algorithm, which are about $414 \mathrm{~W}(15 \%)$ for inductive load and $251 \mathrm{~W}(14 \%)$ for capacitive load, as compared to the existing Modified W-H algorithm with only $386 \mathrm{~W}(14.2 \%)$ for inductive load and $235 \mathrm{~W}(13.1 \%)$ for capacitive load. For irradiance at $200 \mathrm{~W} / \mathrm{m}^{2}$, as shown in Figure $3 \mathrm{c}, \mathrm{d}$, the proposed algorithm reduces the source powers more, which are about $144 \mathrm{~W}(5.3 \%)$ for inductive load and $89 \mathrm{~W}$ (5\%) for capacitive load, as compared to the existing Modified W-H algorithm with only about $124 \mathrm{~W}(4.6 \%)$ for inductive load and $72 \mathrm{~W}(4 \%)$ for capacitive load. The same goes for irradiance at $1000 \mathrm{~W} / \mathrm{m}^{2}$ where the proposed algorithm reduces the source powers higher, which are about $644 \mathrm{~W}(23.7 \%)$ for inductive load and $403 \mathrm{~W}(22.5 \%)$ for capacitive load, as compared to the existing Modified W-H algorithm which only reduces about $614 \mathrm{~W}(22.6 \%)$ for inductive load and $382 \mathrm{~W}(21.3 \%)$ for capacitive load. The proposed algorithm basically extracts accurate current harmonics to produce accurate injection current. With high injection current accuracy, better and precise mitigation of harmonics can be achieved thus lowering use of the source current. Subsequently, reduction of the source power can clearly be seen as compared to the existing Modified W-H algorithm. Tables 4 and 5 show details of the active powers including load power, source power and source power reduction by using both harmonics extraction algorithms for each nonlinear load. Table 6 provides 
detailed comparison of percentages of source power reduction for both algorithms with capacitive and inductive loads. The results show that the FAC ADALINE algorithm has not only helped the SAPF to perform with lower THD values, but also to have high percentage of power reduction, as compared to the existing algorithm.

Table 4. Simulation results of active powers by using FAC ADALINE algorithm.

\begin{tabular}{cccccccc}
\hline & \multicolumn{5}{c}{ Active Power $(\mathbf{k W})$} \\
\cline { 2 - 4 } $\begin{array}{c}\text { Irradiance } \\
\left(\mathbf{W} / \mathbf{m}^{2}\right)\end{array}$ & $\begin{array}{c}\text { Load } \\
\text { Power }\end{array}$ & $\begin{array}{c}\text { Source } \\
\text { Power }\end{array}$ & $\begin{array}{c}\text { Source Power } \\
\text { Reduction }\end{array}$ & & $\begin{array}{c}\text { Load } \\
\text { Power }\end{array}$ & $\begin{array}{c}\text { Source } \\
\text { Power }\end{array}$ & $\begin{array}{c}\text { Source Power } \\
\text { Reduction }\end{array}$ \\
\hline 0 & 2.300 & 2.712 & 0.000 & & 1.520 & 1.791 & 0.000 \\
200 & 2.300 & 2.570 & 0.144 & & 1.520 & 1.705 & 0.089 \\
600 & 2.300 & 2.300 & 0.414 & & 1.520 & 1.543 & 0.251 \\
1000 & 2.300 & 2.070 & 0.644 & & 1.520 & 1.391 & 0.403 \\
\hline
\end{tabular}

Table 5. Simulation results of active powers by using Modified W-H ADALINE algorithm.

\begin{tabular}{|c|c|c|c|c|c|c|}
\hline \multirow{3}{*}{$\begin{array}{c}\text { Irradiance } \\
\left(\mathrm{W} / \mathrm{m}^{2}\right)\end{array}$} & \multicolumn{6}{|c|}{ Active Power (kW) } \\
\hline & \multicolumn{3}{|c|}{ Inductive } & \multicolumn{3}{|c|}{ Capacitive } \\
\hline & $\begin{array}{l}\text { Load } \\
\text { Power }\end{array}$ & $\begin{array}{l}\text { Source } \\
\text { Power }\end{array}$ & $\begin{array}{l}\text { Source Power } \\
\text { Reduction }\end{array}$ & $\begin{array}{l}\text { Load } \\
\text { Power }\end{array}$ & $\begin{array}{l}\text { Source } \\
\text { Power }\end{array}$ & $\begin{array}{l}\text { Source Power } \\
\text { Reduction }\end{array}$ \\
\hline 0 & 2.300 & 2.710 & 0.000 & 1.520 & 1.788 & 0.000 \\
\hline 200 & 2.300 & 2.590 & 0.124 & 1.520 & 1.722 & 0.072 \\
\hline 600 & 2.300 & 2.328 & 0.386 & 1.520 & 1.559 & 0.235 \\
\hline 1000 & 2.300 & 2.10 & 0.614 & 1.520 & 1.412 & 0.382 \\
\hline
\end{tabular}

Table 6. Simulation results of percentage of source power reduction for each harmonics extraction algorithm.

\begin{tabular}{|c|c|c|c|c|c|c|}
\hline \multirow{3}{*}{$\begin{array}{c}\text { Harmonics Extraction } \\
\text { Algorithm }\end{array}$} & \multicolumn{6}{|c|}{ Percentage of Source Power Reduction (\%) } \\
\hline & \multicolumn{3}{|c|}{ Inductive } & \multicolumn{3}{|c|}{ Capacitive } \\
\hline & $0 \mathrm{~W} / \mathrm{m}^{2}$ & $200 \mathrm{~W} / \mathrm{m}^{2}$ & $600 \mathrm{~W} / \mathrm{m}^{2}$ & $0 \mathrm{~W} / \mathrm{m}^{2}$ & $200 \mathrm{~W} / \mathrm{m}^{2}$ & $600 \mathrm{~W} / \mathrm{m}^{2}$ \\
\hline FAC ADALINE & 5.3 & 15 & 23.7 & 5 & 14 & 22.5 \\
\hline Modified W-H ADALINE & 4.6 & 14.2 & 22.6 & 4 & 13.1 & 21.3 \\
\hline
\end{tabular}

In term of response times under dynamic operations during off-on between PV and SAPF, and change of irradiances, the proposed algorithm shows better performance with only response time of $15 \mathrm{~ms}$ (capacitive and inductive). The existing Modified W-H algorithm however needs about $40 \mathrm{~ms}$ (capacitive and inductive), which is two cycles for $50 \mathrm{~Hz}$ system. Additional dynamic operation by changing the nonlinear loads was done, and as referred to Figure 4, the proposed algorithm also produces response time of $15 \mathrm{~ms}$ as compared to the existing algorithm which only gives response time of $40 \mathrm{~ms}$. Performance of dc link capacitor has been investigated too for off-on between PV and $\mathrm{SAPF}$, and change of irradiances from low to high, as shown in Figure 6.

There are negligible overshoots for the capacitor voltage and response time about $0.2-0.3 \mathrm{~s}$, and for both harmonics extraction algorithms, no difference (or same condition) is observed since it is well controlled separately by the self-charging with the step size error cancellation algorithm. These negligible overshoots should ensure both harmonics extraction algorithms are not affected to perform their functions. With better THD values, high percentage of source power reduction and faster response time, the FAC ADALINE algorithm clearly improves performance of harmonics extraction which eventually provides a better SAPF system with integration of the PV source. 

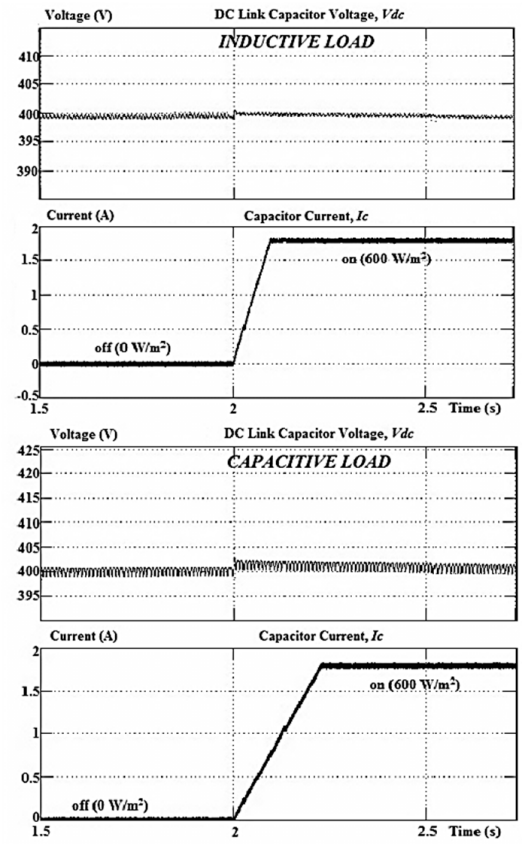

(a)
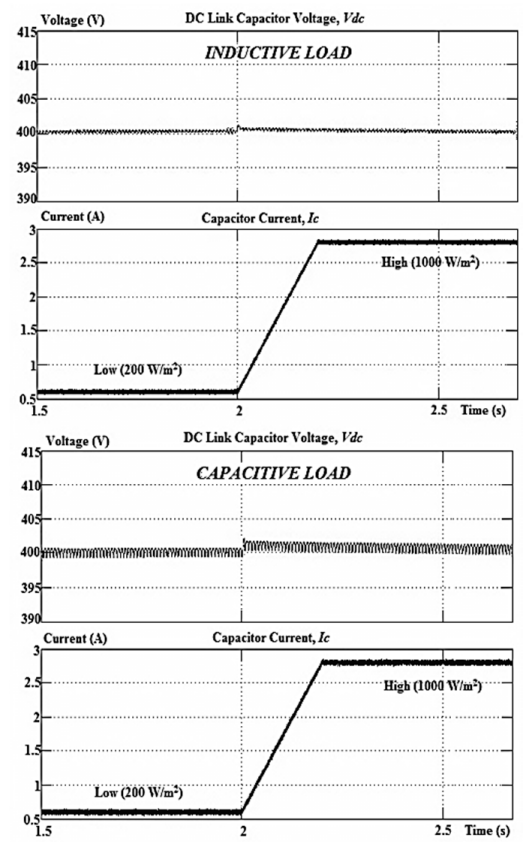

(b)

Figure 6. Performances of dc link capacitor voltage in the simulation work for (a) off-on between PV and SAPF and (b) change of irradiances from low to high.

\section{Experimental Results}

A hardware prototype of the SAPF was developed to further test and verify the proposed algorithm. A PV simulator (62100H-600S, CHROMA, Taoyuan County, Taiwan) was used as PV source by implementing the characteristics of a NT-180U1 PV module (SHARP, Huntington Beach, CA, USA). This prototype used the same load configurations as in the simulation work with voltage source of $100 \mathrm{~V}_{\mathrm{rms}}$ and dc link capacitor voltage of $200 \mathrm{~V}_{\mathrm{dc}}$. A TMS320F28335 digital signal processor (DSP, Texas Instruments, Dallas, TX, USA) was used to implement the harmonics extraction algorithms, together with MPPT, dc link capacitor voltage control, synchronization and current control algorithms. Like in the simulation, two dynamic operations were carried out, which are the off-on operation between PV and SAPF, and change of irradiances from low to high. When PV is in off condition, the irradiance is at $0 \mathrm{~W} / \mathrm{m}^{2}$, and when PV is in on condition, the irradiance is at $600 \mathrm{~W} / \mathrm{m}^{2}$. For the second dynamic operation, low irradiance is set at $200 \mathrm{~W} / \mathrm{m}^{2}$, and meanwhile, high irradiance is set at $1000 \mathrm{~W} / \mathrm{m}^{2}$. Figure 7 shows the results obtained for the first dynamic operation for each harmonics extraction algorithm with two nonlinear loads. Figure 8 shows the second dynamic operation for each harmonics extraction algorithm with two nonlinear loads. Figure 9 shows the additional dynamic operation involving change of nonlinear loads for each harmonics extraction algorithm. Figure 10 shows harmonics spectrum of the nonlinear loads' currents and the source currents for operation of SAPF without PV, by using both harmonics extraction algorithms.

Like in the simulation results, by referring to Figures 7 and 8 the FAC ADALINE algorithm produces better THD values for both dynamic operations. Very good elimination for all harmonic orders is shown in Figure 10, especially with the proposed algorithm. The source current is also in phase with the source voltage. Without PV, THD values obtained are $2.3 \%$ for inductive load and $2.8 \%$ for capacitive load, whereas by using the existing algorithm, THD values are only $3.1 \%$ for inductive load and $3.7 \%$ for capacitive load. When the PV system is operated at $200 \mathrm{~W} / \mathrm{m}^{2}$, the proposed algorithm produces THD values of $2.54 \%$ for inductive load and $3.15 \%$ for capacitive load, and meanwhile, the existing algorithm produces higher THD values of $3.2 \%$ for inductive load and $3.91 \%$ for capacitive load. During irradiance at $600 \mathrm{~W} / \mathrm{m}^{2}$, the proposed algorithm clearly produces 
lower THD values of $2.8 \%$ for inductive load and $3.32 \%$ for capacitive load, as compared to the existing algorithm with $3.75 \%$ and $4.2 \%$ for inductive and capacitive loads respectively. Lastly, for irradiance at $1000 \mathrm{~W} / \mathrm{m}^{2}$, the proposed algorithm produces THD values of $3.2 \%$ and $3.76 \%$ for inductive and capacitive loads respectively. The existing algorithm meanwhile produces THD values of $4.12 \%$ for inductive load and $4.52 \%$ for capacitive load. Table 7 summarizes the overall experimental results of THD for both harmonics extraction algorithms with both nonlinear loads under multiple irradiances.

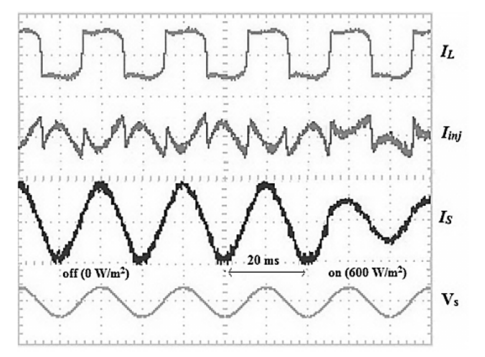

(a)

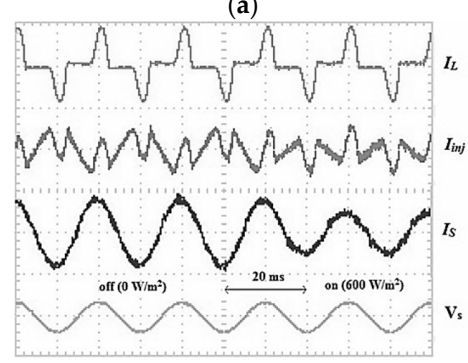

(c)

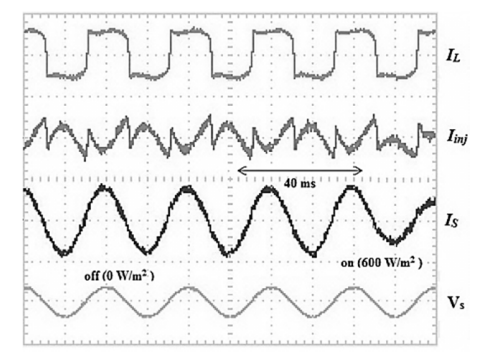

(b)

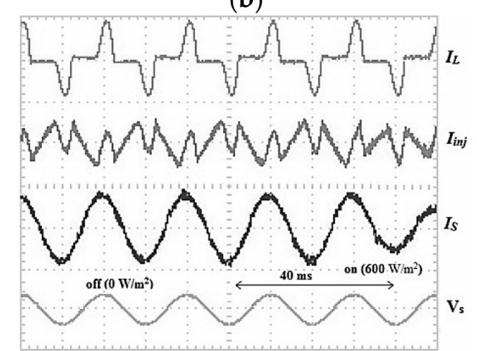

(d)

Figure 7. Experimental results of off-on test which covers the load current $I_{\mathrm{L}}(5 \mathrm{~A} / \mathrm{div})$, the injection current $I_{\text {inj }}(5 \mathrm{~A} /$ div $)$, the source current $I_{\mathrm{S}}(5 \mathrm{~A} / \mathrm{div})$, and the voltage source $V_{\mathrm{S}}(200 \mathrm{~V} / \mathrm{div})$, for (a) FAC ADALINE using inductive load; (b) Modified W-H ADALINE using inductive load; (c) FAC ADALINE using capacitive load and (d) Modified W-H ADALINE using capacitive load.

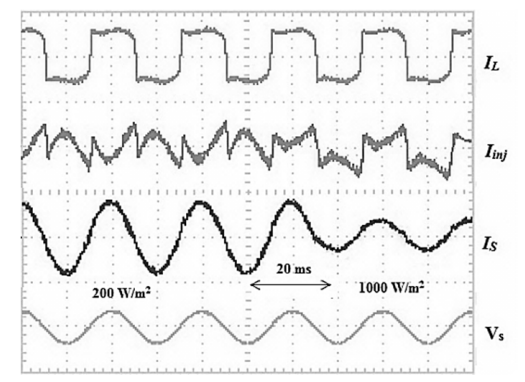

(a)

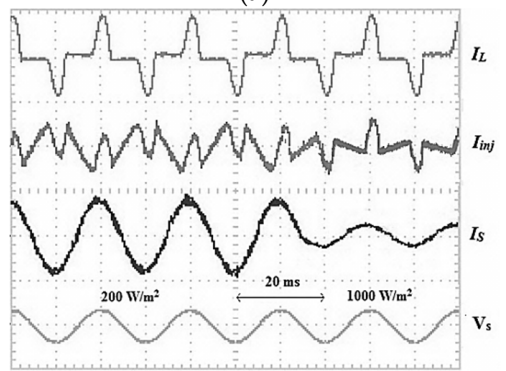

(c)

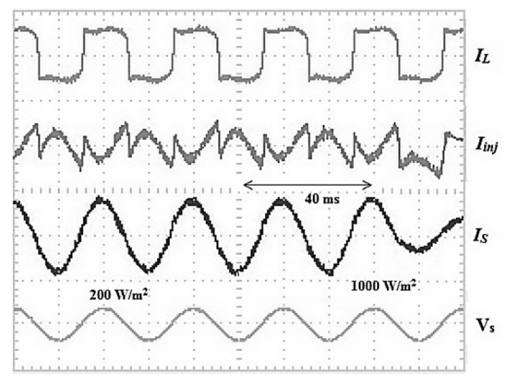

(b)

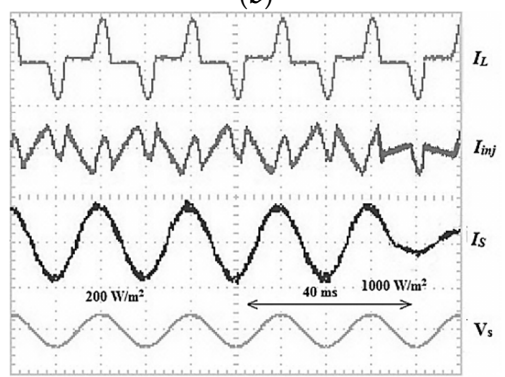

(d)

Figure 8. Experimental results of change of irradiances from low to high which covers the load current $I_{\mathrm{L}}(5 \mathrm{~A} / \mathrm{div})$, the injection current $I_{\text {inj }}(5 \mathrm{~A} / \mathrm{div})$, the source current $I_{\mathrm{S}}(5 \mathrm{~A} / \mathrm{div})$, and the voltage source $V_{\mathrm{S}}(200 \mathrm{~V} /$ div), for (a) FAC ADALINE using inductive load; (b) Modified W-H ADALINE using inductive load; (c) FAC ADALINE using capacitive load and (d) Modified W-H ADALINE using capacitive load. 


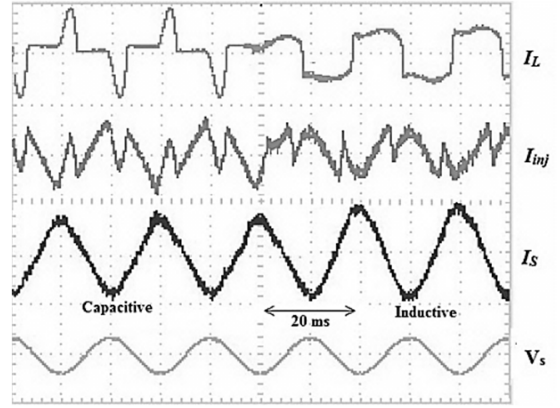

(a)

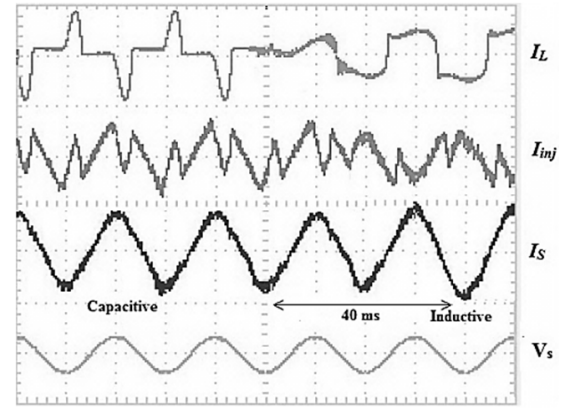

(b)

Figure 9. Experimental results of change of nonlinear load which covers the load current $I_{\mathrm{L}}(5 \mathrm{~A} / \mathrm{div})$, the injection current $I_{\text {inj }}(5 \mathrm{~A} / \mathrm{div})$, the source current $I_{\mathrm{S}}(5 \mathrm{~A} / \mathrm{div})$ and the voltage source $V_{\mathrm{S}}(200 \mathrm{~V} / \mathrm{div})$, for (a) FAC ADALINE and (b) modified W-H ADALINE algorithms.
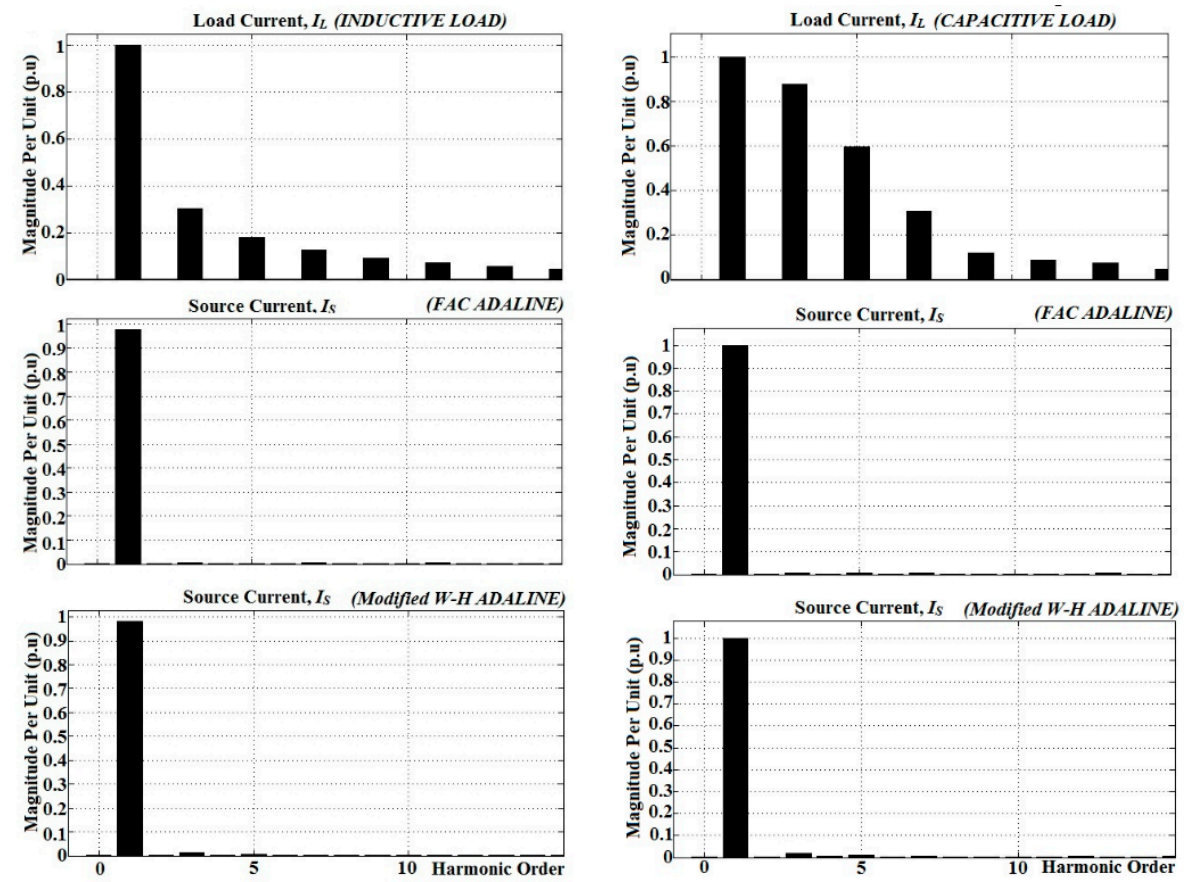

(a)

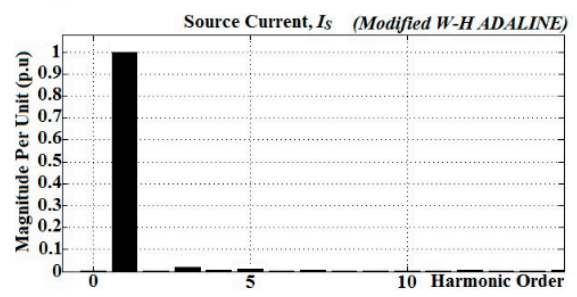

(b)

Figure 10. Harmonics spectrum of experimental work for SAPF without PV, by using both harmonics extraction algorithms, for (a) inductive and (b) capacitive loads.

Table 7. Experimental results of total harmonics distortion for each harmonics extraction algorithm.

\begin{tabular}{|c|c|c|c|c|c|c|c|c|}
\hline \multirow{3}{*}{$\begin{array}{l}\text { Harmonics Extraction } \\
\text { Algorithm }\end{array}$} & \multicolumn{8}{|c|}{ THD (\%) } \\
\hline & \multicolumn{4}{|c|}{ Inductive } & \multicolumn{4}{|c|}{ Capacitive } \\
\hline & $0 \mathrm{~W} / \mathrm{m}^{2}$ & $200 \mathrm{~W} / \mathrm{m}^{2}$ & $600 \mathrm{~W} / \mathrm{m}^{2}$ & $1000 \mathrm{~W} / \mathrm{m}^{2}$ & $0 \mathrm{~W} / \mathrm{m}^{2}$ & $200 \mathrm{~W} / \mathrm{m}^{2}$ & $600 \mathrm{~W} / \mathrm{m}^{2}$ & $1000 \mathrm{~W} / \mathrm{m}^{2}$ \\
\hline FAC ADALINE & 2.3 & 2.54 & 2.8 & 3.2 & 2.8 & 3.15 & 3.32 & 3.76 \\
\hline Modified W-H ADALINE & 3.1 & 3.2 & 3.75 & 4.12 & 3.7 & 3.91 & 4.2 & 4.52 \\
\hline
\end{tabular}

The active powers from the source grid during PV in off condition $\left(0 \mathrm{~W} / \mathrm{m}^{2}\right)$ for inductive and capacitive loads are $450 \mathrm{~W}$ and $380 \mathrm{~W}$, respectively. Meanwhile, load powers are $382 \mathrm{~W}$ for the inductive load and $323 \mathrm{~W}$ for capacitive load. Balanced active powers of $68 \mathrm{~W}$ and $57 \mathrm{~W}$ for inductive and capacitive loads are absorbed by SAPF. The reactive powers produced by using the proposed algorithm are 64 VAR for inductive load and 54 VAR for capacitive load. By using the existing algorithm, the 
reactive powers of the SAPF are 60 VAR for inductive load and 49 VAR for capacitive load. As obtained in the simulation work, higher reactive powers produced by the proposed algorithm shows its better performance of compensation.

By referring to Figures 7 and 8 the proposed algorithm achieves higher source power reduction than the existing algorithm for both nonlinear loads with three different irradiances. When the PV is in on condition at $200 \mathrm{~W} / \mathrm{m}^{2}$, the proposed algorithm achieves a source power reduction of about $23 \mathrm{~W}$ $(4.7 \%)$ for inductive load and $16 \mathrm{~W}(4.3 \%)$ for capacitive load, and meanwhile, the existing algorithm only achieves $20 \mathrm{~W}(4.2 \%)$ reduction for inductive load and $14 \mathrm{~W}(3.8 \%)$ reduction for capacitive load. At $600 \mathrm{~W} / \mathrm{m}^{2}$, the proposed algorithm reduces the source power to about $66 \mathrm{~W}(13.8 \%)$ and $48 \mathrm{~W}$ $(12.5 \%)$ for inductive and capacitive loads respectively, while the existing algorithm only reduces $63 \mathrm{~W}$ $(13.2 \%)$ and $45 \mathrm{~W}(11.9 \%)$ for inductive and capacitive loads respectively. Lastly, at $1000 \mathrm{~W} / \mathrm{m}^{2}$, the proposed algorithm achieves source power reduction in about $110 \mathrm{~W}(23.1 \%)$ for inductive load and $82 \mathrm{~W}(21.5 \%)$ for capacitive load. The existing algorithm meanwhile just reduces the source power in about $108 \mathrm{~W}(22.5 \%)$ and $79 \mathrm{~W}(20.8 \%)$ for inductive and capacitive loads, respectively. Tables 8 and 9 show details of the experimental results for active powers including load power, source power and source power reduction using both harmonics extraction algorithms for each nonlinear load. Table 10 provides detailed comparison of percentage of the source power reduction for both algorithms with capacitive and inductive loads. Subsequently, both results from THD value and percentage of source power reduction show significant correlation. Lower THD value contributes to lower power required from the grid as clearly achieved by the proposed algorithm.

Table 8. Experimental results of active powers by using FAC ADALINE algorithm.

\begin{tabular}{cccccccc}
\hline \multirow{2}{*}{$\begin{array}{c}\text { Irradiance } \\
\left(\mathbf{W} / \mathbf{m}^{2}\right)\end{array}$} & \multicolumn{3}{c}{ Anductive } & & \multicolumn{3}{c}{ Capacitive } \\
\cline { 2 - 4 } \cline { 6 - 8 } & $\begin{array}{c}\text { Load } \\
\text { Power }\end{array}$ & $\begin{array}{c}\text { Source } \\
\text { Power }\end{array}$ & $\begin{array}{c}\text { Source Power } \\
\text { Reduction }\end{array}$ & & $\begin{array}{c}\text { Load } \\
\text { Power }\end{array}$ & $\begin{array}{c}\text { Source } \\
\text { Power }\end{array}$ & $\begin{array}{c}\text { Source Power } \\
\text { Reduction }\end{array}$ \\
\hline 0 & 0.382 & 0.448 & 0.000 & & 0.323 & 0.378 & 0.000 \\
200 & 0.382 & 0.427 & 0.023 & & 0.323 & 0.364 & 0.016 \\
600 & 0.382 & 0.384 & 0.066 & & 0.323 & 0.332 & 0.048 \\
1000 & 0.382 & 0.340 & 0.110 & & 0.323 & 0.298 & 0.082 \\
\hline
\end{tabular}

Table 9. Experimental results of active powers by using Modified W-H ADALINE algorithm.

\begin{tabular}{cccccccc}
\hline \multirow{2}{*}{$\begin{array}{c}\text { Irradiance } \\
\left(\mathbf{W} / \mathbf{m}^{2}\right)\end{array}$} & \multicolumn{3}{c}{ Inductive } & & \multicolumn{3}{c}{ Capacitive } \\
\cline { 2 - 4 } \cline { 7 - 8 } & $\begin{array}{c}\text { Load } \\
\text { Power }\end{array}$ & $\begin{array}{c}\text { Source } \\
\text { Power }\end{array}$ & $\begin{array}{c}\text { Source Power } \\
\text { Reduction }\end{array}$ & & $\begin{array}{c}\text { Load } \\
\text { Power }\end{array}$ & $\begin{array}{c}\text { Source } \\
\text { Power }\end{array}$ & $\begin{array}{c}\text { Source Power } \\
\text { Reduction }\end{array}$ \\
\hline 0 & 0.382 & 0.446 & 0.000 & & 0.323 & 0.375 & 0.000 \\
200 & 0.382 & 0.430 & 0.020 & & 0.323 & 0.366 & 0.014 \\
600 & 0.382 & 0.387 & 0.063 & & 0.323 & 0.335 & 0.045 \\
1000 & 0.382 & 0.342 & 0.108 & & 0.323 & 0.301 & 0.079 \\
\hline
\end{tabular}

Table 10. Experimental results of percentage of source power reduction for each harmonics extraction algorithm.

\begin{tabular}{|c|c|c|c|c|c|c|}
\hline \multirow{3}{*}{$\begin{array}{c}\text { Harmonics Extraction } \\
\text { Algorithm }\end{array}$} & \multicolumn{6}{|c|}{ Percentage of Source Power Reduction (\%) } \\
\hline & \multicolumn{3}{|c|}{ Inductive } & \multicolumn{3}{|c|}{ Capacitive } \\
\hline & $0 \mathrm{~W} / \mathrm{m}^{2}$ & $200 \mathrm{~W} / \mathrm{m}^{2}$ & $600 \mathrm{~W} / \mathrm{m}^{2}$ & $0 \mathrm{~W} / \mathrm{m}^{2}$ & $200 \mathrm{~W} / \mathrm{m}^{2}$ & $600 \mathrm{~W} / \mathrm{m}^{2}$ \\
\hline FAC ADALINE & 4.7 & 13.8 & 23.1 & 4.3 & 12.5 & 21.5 \\
\hline Modified W-H ADALINE & 4.2 & 13.2 & 22.5 & 3.8 & 11.9 & 20.8 \\
\hline
\end{tabular}


For the response time of the harmonics extraction algorithms one can be refer to Figures 7 and 8 where during the first dynamic operation, the proposed algorithm shows faster response time for both nonlinear loads, with only $20 \mathrm{~ms}$ taken to respond to the change due to the PV being turned on. The existing algorithm needs $40 \mathrm{~ms}$, which is $20 \mathrm{~ms}$ delay. The same goes for the second dynamic operation where the proposed algorithm shows faster response time for both nonlinear loads with also $20 \mathrm{~ms}$ to respond from low to high irradiance, whereas the existing algorithm takes $40 \mathrm{~ms}$. For the performance under change of nonlinear loads, by referring to Figure 9, the proposed algorithm shows a faster response time $(20 \mathrm{~ms})$ as compared to the existing algorithm $(40 \mathrm{~ms})$. Figure 11 shows the performances of the dc link capacitor, and there are negligible overshoots for the capacitor voltage with a response time of $0.3 \mathrm{~s}$, and for both extraction harmonics algorithms, no difference is observed, which verifies they are not affected to perform their roles. With faster response time, and also higher power reduction and better THD value, the FAC ADALINE algorithm has clearly shown its better performance as a harmonic extraction algorithm in SAPF as compared to the Modified W-H ADALINE algorithm.

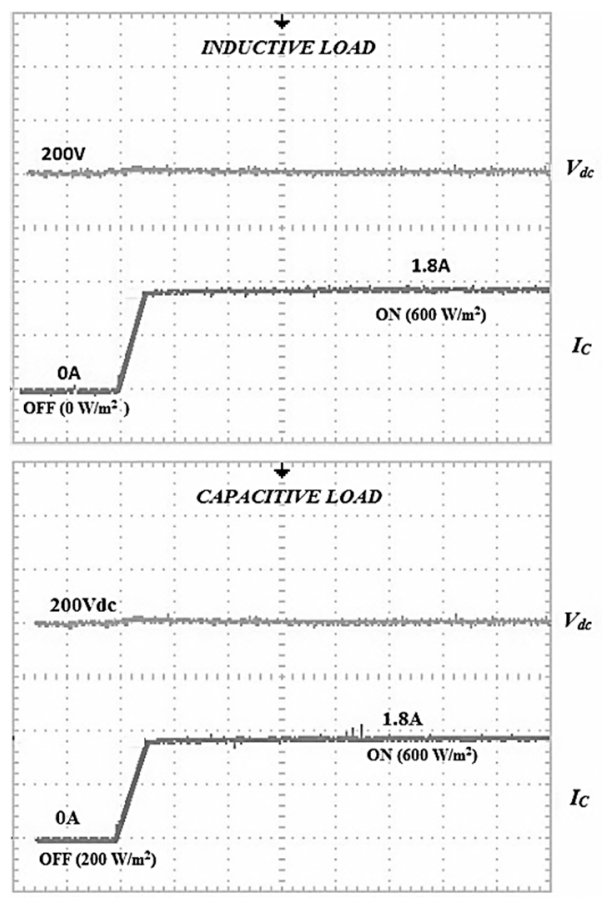

(a)

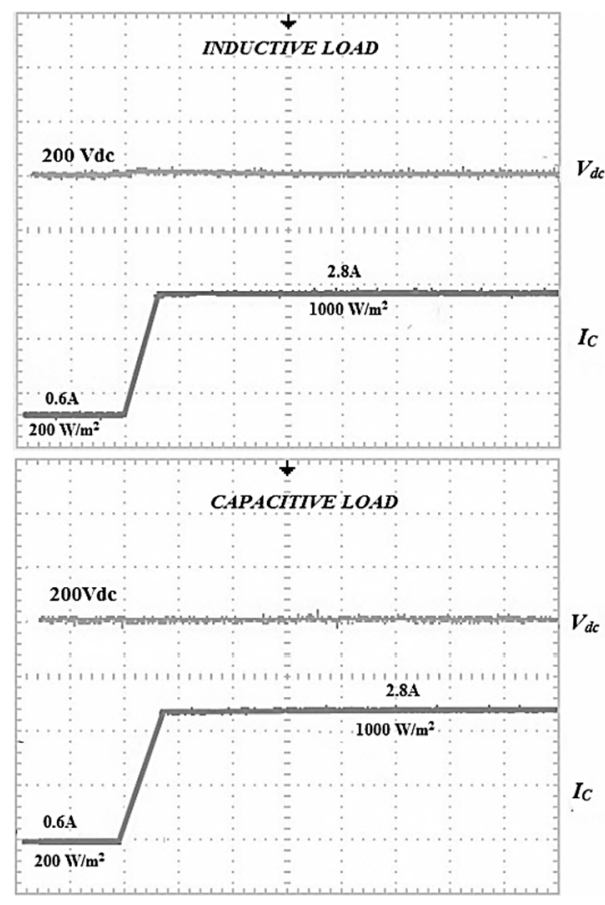

(b)

Figure 11. Performances of dc link capacitor voltage in the experimental work for (a) off-on between PV and SAPF and (b) change of irradiances from low to high.

\section{Conclusions}

This paper has presented two major contributions, first by integrating PV to SAPF, and second by developing a simplified and improved harmonics extraction algorithm called FAC ADALINE algorithm. Integration of PV has contributed to generation of active PV current to facilitate the operation of SAPF, and at the same time to supply power to the load. Meanwhile, the proposed FAC ADALINE algorithm, with its high accuracy and fast response time has successfully demnstrated better performance, not just during steady state, but most importantly in dynamic operations. The simulation work has confirmed that the proposed algorithm is able to achieve lower THD values, which directly represent high accuracy of harmonics extraction. In addition, it has also performed with fast response time during two dynamic operations, both for off-on between PV and SAPF, and change of PV's irradiances. Significant reduction of power supplied from the grid has been shown clearly in this work when PV is connected. Experimental work has further confirmed effectiveness of the proposed 
algorithm through both steady state and dynamic operations as carried out in the simulation work. Therefore, the new FAC ADALINE algorithm has successfully improved the performance for harmonics extraction, especially for SAPF connected with PV.

Acknowledgments: This work is supported by the Putra Research Gant Scheme under the Universiti Putra Malaysia, Malaysia (9447800).

Author Contributions: Muhammad Ammirrul Atiqi Mohd Zainuri designed and developed the main parts of the research work, including simulation model, experimental set up, and analyses of the obtained results. Muhammad Ammirrul Atiqi Mohd Zainuri was also mainly responsible for preparing the paper. Mohd Amran Mohd Radzi contributed in simulation, experimental, and writing parts. Azura Che Soh, Nasrudin Abd Rahim and Shahrooz Hajighorbani also involved in verifying the work and actively contributed to finalize the manuscript.

Conflicts of Interest: The authors declare no conflict of interest.

\section{References}

1. Hu, H.; Shi, Q.; He, Z.; He, J.; Gao, S. Potential harmonic resonance impacts of PV inverter filters on distribution systems. IEEE Trans. Sustain. Energy 2015, 6, 151-161. [CrossRef]

2. Bouloumpasis, I.; Vovos, P.; Georgakas, K.; Vovos, N.A. Current Harmonics Compensation in Microgrids Exploiting the Power Electronics Interfaces of Renewable Energy Sources. Energies 2015, 8, 2295-2311. [CrossRef]

3. Zhou, Y.; Li, H. Analysis and suppression of leakage current in cascaded-multilevel-inverter-based PV systems. IEEE Trans. Power Electron. 2014, 29, 5265-5277. [CrossRef]

4. He, G.; Xu, D.; Chen, M. A novel control strategy of suppressing DC current injection to the grid for single-phase PV inverter. IEEE Trans. Power Electron. 2015, 30, 1266-1274. [CrossRef]

5. Keyhani, H.; Toliyat, H.A. Single-stage multistring PV inverter with an isolated high-frequency link and soft-switching operation. IEEE Trans. Power Electron. 2014, 29, 3919-3929. [CrossRef]

6. Carcangiu, G.; Dainese, C.; Faranda, R.; Leva, S.; Sardo, M. New network topologies for large scale Photovoltaic Systems. In Proceedings of the IEEE Bucharest Power Tech Conference, Bucharest, Romania, 28 June-2 July 2009; pp. 1-7.

7. Zhou, N.; Wang, J.; Wang, Q.; Wei, N.; Lou, X. Capacity calculation of shunt active power filters for electric vehicle charging stations based on harmonic parameter estimation and analytical modeling. Energies 2014, 7, 5425-5443. [CrossRef]

8. Dolara, A.; Leva, S. Power quality and harmonic analysis of end user devices. Energies 2012, 5, 5453-5466. [CrossRef]

9. Badoni, M.; Singh, A.; Singh, B. Adaptive recursive inverse-based control algorithm for shunt active power filter. IET Power Electron. 2016, 9, 1053-1064. [CrossRef]

10. Rajesh, T.; Aravindhan, S.; Sowmiya, M.; Thenmozhi, S.; Professor, A.; Scholar, U.G. Design of Shunt Active Filter for Reduction of Harmonics. Int. J. Eng. Sci. 2016, 6, 3317-3321.

11. Ray, A.S.; Bhattacharya, A. Improved tracking of shunt active power filter by sliding mode control. Int. J. Electr. Power Energy Syst. 2016, 78, 916-925.

12. Pejović, P.; Shmilovitz, D. Low-harmonic thyristor rectifiers applying current injection. IEEE Trans. Aerosp. Electron. Syst. 2003, 39, 1365-1374. [CrossRef]

13. Shmilovitz, D. Loss-free complex impedance network elements. IEEE Trans. Circuits Syst. I Regul. Pap. 2006, 53, 704-711. [CrossRef]

14. Faranda, R.; Leva, S. Energy comparison of MPPT techniques for PV Systems. WSEAS Trans. Power Syst. 2008, 3, 446-455.

15. Feldman, D.; Barbose, G.; Margolis, R.; Wiser, R.; Darghouth, N.; Goodrich, A. Photovoltaic (PV) Pricing Trends: Historical, Recent, and Near-Term Projections; Lawrence Berkeley National Laboratory, University of California: Oakland, CA, USA, 2012; pp. 1-22.

16. Fthenakis, V.; Kim, H.C.; Frischknecht, R.; Raugei, M.; Sinha, P.; Stucki, M. Life cycle inventories and life cycle assessment of photovoltaic systems. Int. Energy Agency IEA PVPS Task 2011, 12, 1-63.

17. Jordan, D.C.; Kurtz, S.R. Photovoltaic degradation rates-An analytical review. Prog. Photovolt. Res. Appl. 2013, 21, 12-29. [CrossRef] 
18. Si, L.; Qiu, T.; Zhang, W.; Chu, P.K. Recent progress in design of plasmonic thin-film solar cells with enhanced efficiency. Recent Pat. Mater. Sci. 2012, 5, 166-172. [CrossRef]

19. Sethi, V.K.; Pandey, M.; Shukla, M.P. Use of nanotechnology in solar PV cell. Int. J. Chem. Eng. Appl. 2011, 2, 77-80. [CrossRef]

20. ISIS Malaysia. Reforming Peninsular Malaysia's Electricity Sector: Challenges and Prospects; Kuala Lumpur: Institute of Strategic and international Studies (ISIS) Malaysia: Kuala Lumpur, Malaysia, 2014; pp. 1-40.

21. Rachid, C.; Yahia, B.; Hind, D. Application of an Active Power Filter on Photovoltaic Power Generation System. Int. J. Renew. Energy Res. IJRER 2012, 2, 583-590.

22. Belaidi, R.; Haddouche, A.; Hatti, M.; Larafi, M.M. Shunt active power filter connected to a photovoltaic array for compensating harmonics and reactive power simultaneously. In Proceedings of the Fourth International Conference on Power Engineering, Energy and Electrical Drives (POWERENG), Istanbul, Turkey, 13-17 May 2013; pp. 1482-1486.

23. Vijayakumar, G.; Anita, R. Photovoltaic Based Shunt Active Filter For Power Quality Improvement Using I $\cos \varphi$ Theory. J. Eng. Sci. Technol. 2015, 10, 1422-1440.

24. Dall'Anese, E.; Dhople, S.V.; Giannakis, G. Optimal dispatch of photovoltaic inverters in residential distribution systems. IEEE Trans. Sustain. Energy 2014, 5, 487-497. [CrossRef]

25. Chuang, Y.C.; Ke, Y.L.; Chuang, H.S.; Wang, Y.S. A novel single-switch resonant power converter for renewable energy generation applications. IEEE Trans. Ind. Appl. 2014, 50, 1322-1330. [CrossRef]

26. Barater, D.; Buticchi, G.; Lorenzani, E.; Concari, C. Active common-mode filter for ground leakage current reduction in grid-connected PV converters operating with arbitrary power factor. IEEE Trans. Ind. Electron. 2014, 61, 3940-3950. [CrossRef]

27. Sujitjom, S.; Areerak, K.L.; Kulworawanichpong, T. The DQ axis with fourier (DQF) method for harmonic identification. IEEE Trans. Power Deliv. 2007, 22, 737-739. [CrossRef]

28. Dey, P.; Mekhilef, S. Current harmonics compensation with three-phase four-wire shunt hybrid active power filter based on modified D-Q theory. IET Power Electron. 2015, 8, 2265-2280. [CrossRef]

29. Mikkili, S.; Panda, A.K. Types-1 and-2 fuzzy logic controllers-based shunt active filter $I_{d}-I_{q}$ control strategy with different fuzzy membership functions for power quality improvement using RTDS hardware. IET Power Electron. 2013, 6, 818-833. [CrossRef]

30. Akagi, H.; Kanazawa, Y.; Nabae, A. Instantaneous reactive power compensators comprising switching devices without energy storage components. IEEE Trans. Ind. Appl. 1984, 3, 625-630. [CrossRef]

31. Karimi, H.; Karimi-Ghartemani, M.; Iravani, M.R.; Bakhshai, A.R. An adaptive filter for synchronous extraction of harmonics and distortions. IEEE Trans. Power Deliv. 2003, 18, 1350-1356. [CrossRef]

32. Forghani, M.; Afsharnia, S. Online wavelet transform-based control strategy for UPQC control system. IEEE Trans. Power Deliv. 2007, 22, 481-491. [CrossRef]

33. Zeng, F.P.; Tan, G.H.; Wang, J.Z.; Ji, Y.C. Novel single-phase five-level voltage-source inverter for the shunt active power filter. IET Power Electron. 2010, 3, 480-489. [CrossRef]

34. Chen, C.L.; Lin, C.E.; Huang, C.L. Reactive and harmonic current compensation for unbalanced three-phase systems using the synchronous detection method. Electr. Power Syst. Res. 1993, 26, 163-170. [CrossRef]

35. Radzi, M.M.A.; Rahim, N.A. Neural network and bandless hysteresis approach to control switched capacitor active power filter for reduction of harmonics. IEEE Trans. Ind. Electron. 2009, 56, 1477-1484. [CrossRef]

36. Tey, L.H.; So, P.L.; Chu, Y.C. Improvement of power quality using adaptive shunt active filter. IEEE Trans. Power Deliv. 2005, 20, 1558-1568. [CrossRef]

37. Sahu, L.D.; Dubey, S.P. ANN based Hybrid Active Power Filter for Harmonics Elimination with Distorted Mains. Int. J. Power Electron. Driv. Syst. 2012, 2, 241-248. [CrossRef]

38. Lega, A.; Mengoni, M.; Serra, G.; Tani, A.; Zarri, L. General theory of space vector modulation for five-phase inverters. In Proceedings of the IEEE International Symposium on Industrial Electronics, Cambridge, UK, 30 June-2 July 2008; pp. 237-244.

39. Saribulut, L.; Teke, A.; Tümay, M. Artificial neural network-based discrete-fuzzy logic controlled active power filter. IET Power Electron. 2014, 7, 1536-1546. [CrossRef]

40. Cirrincione, M.; Pucci, M.; Vitale, G. A single phase DG generation unit with shunt active power filter capability by adaptive neural filtering. IEEE Trans. Ind. Electron. 2008, 55, 2093-2110. [CrossRef] 
41. Rahman, N.F.A.; Radzi, M.A.M.; Mariun, N.; Soh, A.C.; Rahim, N.A. Integration of dual intelligent algorithms in shunt active power filter. In Proceednigs of the 2013 IEEE Conference on Clean Energy and Technology (CEAT), Langkawi, Malaysia, 18-20 November 2013; pp. 259-264.

42. Bhattacharya, A.; Chakraborty, C. Adaline controlled 3-phase 3-wire shunt active power filter with enhanced performance using the capacitor voltage feedback. In Proceedings of the IEEE International Conference on Industrial Technology, Gippsland, VIC, Australia, 10-13 February 2009; pp. 1-6.

43. Mohd Zainuri, M.; Radzi, M.; Soh, A.C.; Rahim, N.A. Development of adaptive perturb and observe-fuzzy control maximum power point tracking for photovoltaic boost dc-dc converter. IET Renew. Power Gener. 2014, 8, 183-194. [CrossRef]

44. Zainuri, M.A.A.M.; Radzi, M.A.M.; Soh, A.C.; Mariun, N.; Rahim, N.A. DC-link capacitor voltage control for single-phase shunt active power filter with step size error cancellation in self-charging algorithm. IET Power Electron. 2015, 9, 323-335. [CrossRef]

45. Buso, S.; Malesani, L.; Mattavelli, P. Comparison of current control techniques for active filter applications. IEEE Trans. Ind. Electron. 1998, 45, 722-729. [CrossRef]

46. Rahman, N.F.A.; Radzi, M.A.M.; Soh, A.C.; Mariun, N.; Rahim, N.A. Dual Function of Unified Adaptive Linear Neurons Based Fundamental Component Extraction Algorithm for Shunt Active Power Filter Operation. Int. Rev. Electr. Eng. IREE 2015, 10, 544-552. [CrossRef]

47. Campanhol, G.; Leonardo, B.; Oliveira da Silva, S.A.; Goedtel, A. Application of shunt active power filter for harmonic reduction and reactive power compensation in three-phase four-wire systems. IET Power Electron. 2014, 7, 2825-2836. [CrossRef]

48. Liu, Q.; Deng, Y.; He, X. Boost-type inverter-less shunt active power filter for VAR and harmonic compensation. IET Power Electron. 2013, 6, 535-542. [CrossRef]

49. Panigrahi, R.; Subudhi, B.; Panda, P.C. Model predictive-based shunt active power filter with a new reference current estimation strategy. IET Power Electron. 2015, 8, 221-233. [CrossRef]

50. Gomez Jorge, S.; Busada, C.A.; Solsona, J.A. Reduced order generalised integrator-based current controller applied to shunt active power filters. IET Power Electron. 2014, 7, 1083-1091. [CrossRef]

51. Khadem, S.K.; Basu, M.; Conlon, M.F. Harmonic power compensation capacity of shunt active power filter and its relationship with design parameters. IET Power Electron. 2014, 7, 418-430. [CrossRef]

52. Xiao, Z.; Deng, X.; Yuan, R.; Guo, P.; Chen, Q. Shunt active power filter with enhanced dynamic performance using novel control strategy. IET Power Electron. 2014, 7, 3169-3181. [CrossRef]

53. Salcone, M.; Bond, J. Selecting Film Bus Link Capacitors for High Performance Inverter Applications. In Proceedings of the IEEE International Electric Machines and Drives Conference, Miami, FL, USA, 3-6 May 2009; pp. 1692-1699.

54. Cao, W.; Liu, K.; Ji, Y.; Wang, Y.; Zhao, J. Design of a Four-Branch LCL-Type Grid-Connecting Interface for a Three-Phase, Four-Leg Active Power Filter. Energies 2015, 8, 1606-1627. [CrossRef]

55. Wang, W.; Luo, A.; Xu, X.; Fang, L.; Chau, T.M.; Li, Z. Space vector pulse-width modulation algorithm and DC-side voltage control strategy of three-phase four-switch active power filters. IET Power Electron. 2013, 6, 125-135. [CrossRef]

(C) 2016 by the authors; licensee MDPI, Basel, Switzerland. This article is an open access article distributed under the terms and conditions of the Creative Commons Attribution (CC-BY) license (http://creativecommons.org/licenses/by/4.0/). 